\title{
TRABALHO ESCRAVO NO BRASIL CONTEMPORÂNEO
}

\section{Daniel Queiroz Pereira ${ }^{1}$ \\ Raísa Lessa dos Anjos ${ }^{2}$}

\section{Resumo}

O escopo do presente trabalho consiste em avaliar as formas de escravidão existentes no Brasil contemporâneo, $\mathrm{o}$ seu conceito atual, suas possíveis causas e os personagens envolvidos. Será exposto um breve histórico do direito trabalhista e da escravidão e, a seguir, será avaliado quais são os principais direitos violados com a sua prática e os principais fatores para a sua persistência. Contém a descrição das medidas governamentais e não governamentais para erradicar o crime de submeter alguém à condição análoga à de escravo, como as leis existentes, os programas sociais e os tratados internacionais ratificados pelo Brasil. O objetivo é relatar uma prática comum no país, realizada de forma dissimulada e quase imperceptível, com a finalidade de conscientizar a sociedade sobre o problema, destacar a importância da assistência aos trabalhadores resgatados e analisar o que ainda pode ser feito para o combater a submissão de um cidadão à condições sub humanas.

Palavras-Chave: Escravidão; Plano Nacional para Erradicação do Trabalho Escravo; Convenções e tratados internacionais .

\section{INTRODUÇÃO}

O trabalho escravo foi um modelo de produção utilizado em todo o mundo, sob diversas formas e diferentes épocas, sendo considerado, por muitos séculos, uma prática legal, justificável e eficiente.

Com a generalização do trabalho assalariado e o avanço dos direitos trabalhistas, a partir do século XIX, diversos países deixaram de adotar a mão de obra escrava e passaram a exercer grande pressão para que os demais Estados também proibissem essa prática em seus territórios.

No Brasil, o direito de propriedade sobre outra pessoa teve seu fim decretado em 13 de maio de 1888, com a assinatura da Lei Áurea pela Princesa Isabel. No entanto, embora universalmente condenado, passados mais de um século desde a extinção da escravidão, esse problema ainda persiste.

\footnotetext{
${ }^{1}$ Professor Adjunto de Legislação Social da Universidade Federal do Estado do Rio de Janeiro - UNIRIO. Assistente de pesquisas da Editora Atlas S.A. Doutor em Direito da Cidade pela Universidade do Estado do Rio de Janeiro - UERJ. E-mail: danielqueiroz.unirio@gmail.com.

${ }^{2}$ Bacharel em Direito pela Universidade Federal do Estado do Rio de Janeiro - UNIRIO. E-mail: raisalessa@hotmail.com vol.08, nº. 03, Rio de Janeiro, 2015.pp. 1334-1368 1334
} 
Com a falta de amparo, assistência legal e o alto índice de desemprego, muitas classes são vítimas e excluídas da sociedade. Com isso, para garantir a sua sobrevivência e da família, milhares de trabalhadores são enganados, iludidos e submetidos às condições desumanas.

As dívidas contraídas pelos trabalhadores com transporte, alimentação e vestuário, o isolamento geográfico em que ficam submetidos e a imposição a longas horas de trabalho pelos escravocratas através de castigos físicos e a vigilância por guardas armados são razões que contribuem para a persistência da escravidão no Brasil, dificultando a fuga e impedindo que os aliciados tenham uma vida digna, defendida na nossa Lei Maior.

Os escravocratas contemporâneos, em sua maioria grandes latifundiários, possuem baixíssimos custos para manter um trabalhador forçado em sua propriedade, pois não garantem o mínimo necessário para que o ser humano tenha uma vida com qualidade, contrastando com as significativas mudanças e avanços nas garantias dos direitos trabalhistas brasileiros ao longo dos séculos.

O conceito de submeter alguém à condição análoga à de escravo sofreu mudanças para melhor caracterizar o crime previsto no Código Penal e atualmente é entendido como submeter alguém a trabalhos forçados, jornada exaustiva, condições degradantes ou restringir a sua locomoção em razão de dívida contraída, a chamada servidão por dívida.

Dessa forma, o trabalho degradante, aquele que não possui condições mínimas de saúde, higiene e segurança, passou a ser caracterizado como trabalho análogo à condição de escravo, pois fere os princípios constitucionais e trabalhistas. Assim, conforme o direito positivado, não é preciso que o trabalhador sofra restrição da sua liberdade para que seja considerado vítima dessa prática ilegal. Possuir um ambiente de trabalho em péssimas condições, como não ter saneamento básico e água potável também caracteriza a exploração ilegal do trabalho com fins econômicos.

Tendo em vista que o trabalho em condições análogas à condição de escravo, que abrange o forçado e o degradante, fere a própria legislação brasileira, como a Consolidação das Leis trabalhistas, o Código Penal e a Constituição Federal, deve-se buscar combatê-lo, a fim de que prevaleça a justiça social, com trabalho digno e decente para todos os trabalhadores.

A informação e conscientização da sociedade sobre o combate ao trabalho escravo contemporâneo é uma importante ferramenta para libertar às vítimas desse trabalho indigno e abolir de vez essa prática ilegal que persiste no nosso país. 


\section{TRABALHO ESCRAVO}

$\mathrm{O}$ ato de trabalhar sempre esteve presente na sociedade, desde a antiguidade. Mas que, ao passar do tempo, teve suas características e seu significado modificados.

A palavra trabalho vem do latim "tripalium", um instrumento de tortura usado naqueles que perderam sua liberdade e eram obrigados a trabalhar. Por vários séculos, o trabalho foi visto como um fardo.

Nos dias atuais, a tutela do valor-trabalho pelo Estado é essencial, pois fundamenta o Estado de Direito e é o esteio da organização econômica do país. A proteção do trabalho significa proteger o próprio homem e sua dignidade, pois há a proteção da sociedade em que o homem se insere 3 .

No entanto, a exploração do trabalho e do homem pelo homem é tão antiga quanto a humanidade. Como dito anteriormente, a escravidão é considerada a primeira forma de trabalho e permanece até os dias atuais.

Nos séculos passados, a escravização de grupos considerados inferiores era um fato justificável, compreensível e legal. Nos modos contemporâneos de escravização do homem, não há grupos considerados estrangeiros, escraviza-se qualquer homem, inclusive do grupo do próprio escravizador ${ }^{4}$.

Apesar da proteção do Estado e dos Organismos Internacionais, mais de um século depois do surgimento do Direito do Trabalho, a exploração cruel do homem ainda persiste e se tornou uma das grandes preocupações mundiais.

\section{Conceito de Trabalho Escravo}

Neste sentido, a primeira dificuldade que surge reside na conceituação do termo Trabalho Escravo. Apesar da legislação brasileira, por meio do artigo 149 do Código Penal, prever os elementos caracterizadores, ainda há divergências doutrinárias sobre a denominação deste ilícito.

A partir de 13 de maio de 1888, o Estado passou a considerar ilegal a prática de possuir uma pessoa, não sendo mais possível um ser humano ser dono de outro. Dessa forma, o termo "Trabalho Escravo", juridicamente, não é utilizado, tendo sido abolido com a Lei Áurea. O que teve permanência foram situações semelhantes da escravização, como a supressão da liberdade e a violação de direitos fundamentais.

Com o advento da Lei n 10.803 de 11 de dezembro de 2003, o Código Penal Brasileiro passou a prever o crime como redução do trabalhador à condição análoga à de escravo.

A escravização mudou apenas juridicamente, a essência desse ilícito continua como se via há séculos atrás. O homem escravizado atualmente está tão suscetível à exploração quanto antes, sendo tratado como objeto,

\footnotetext{
${ }^{3}$ Trabalho Escravo Contemporâneo: o desafio de superar a negação./ Andrea Saint Pastous Nocchi, Gabriel Napolão Velloso, Marcos Neves Fava, coordenadores. $2^{\circ}$ edição. São Paulo: Ltr, 2011, pp. 11.

${ }^{4}$ Trabalho Escravo Contemporâneo: o desafio de superar a negação./ Andrea Saint Pastous Nocchi, Gabriel Napolão Velloso, Marcos Neves Fava, coordenadores. $2^{\circ}$ edição. São Paulo: Ltr, 201 1, pp. 14-15.
} vol.08, no.03, Rio de Janeiro, 2015.pp. 1334-1368 1336 
como coisa. Por isso, trataremos do tema como Trabalho Escravo Contemporâneo, conceituando-o, em poucas palavras, como ato violador dos Direitos Humanos.

Desta forma, afirma Evanna Soares:

Considerando tal essência do trabalho, ou melhor, do trabalho em condições análogas à escravidão - expressão mais apropriada aos dias atuais em que a escravidão é proibida pelos povos civilizados - tem-se como exploração de mão de obra em tais condições todos os casos em que a dignidade humana é aviltada, notadamente quando o trabalhador é iludido com promessas de bons salários e transportado sem obediência aos requisitos legais, ou impedido de sair do local de trabalho pela vigilância armada ou preso a dívidas impagáveis contraídas perante o empregador, ou, ainda, explorado sem atenção aos direitos trabalhistas elementares, tais o salário mínimo, jornada de trabalho normal, pagamento de adicionais, repouso remunerado e boas condições de higiene, saúde e segurança do trabalho. ${ }^{5}$

A afirmação de que a escravização viola a dignidade da pessoa humana é unânime no mundo, porém, diferentemente da Organização Internacional do Trabalho (OIT), que acredita que o trabalho forçado é gênero e comporta diversas espécies, a legislação brasileira considera que o Trabalho análogo ao de escravo é gênero do qual podemos verificar as seguintes espécies: trabalho forçado, jornada exaustiva, condições degradantes e servidão por dívida. Há ainda as hipóteses de trabalho escravo por equiparação: retenção no local do trabalho, por cerceamento do uso de qualquer meio de transporte, manutenção de vigilância ostensiva, e a retenção de documentos ou objetos de uso pessoal do trabalhador; sempre em função da dívida e com a finalidade de mantêlos no local de trabalho.

O trabalhador escravizado, atualmente, cede sua força de trabalho ou continua na relação laboral por vício de vontade. Podendo ocorrer o dolo, simulação, fraude, coação ou indução a erro no início, durante ou ao final da contratação.

O vício de vontade pode ser de ordem moral, psicológica ou física. Quanto à ordem moral temos a escravização por dívida, em que o trabalhador é induzido a acreditar que é devedor de dívidas e está impossibilitado de deixar o local de trabalho enquanto não quitá-las. A coação psicológica está presente quando o escravizado é vítima de constantes ameaças de morte, agressão ou abandono para que preste serviço ao empregador. E, por fim, a coação física se caracteriza por agressões físicas e até mesmo por morte, no caso de tentativa de fuga ou rejeição à condição de escravo ${ }^{6}$.

Deduz-se que para a caracterização do trabalho escravo, não é imprescindível que o trabalhador seja coagido a permanecer prestando serviços, pois existem situações em que o trabalhador presta serviços,

\footnotetext{
${ }^{5}$ Revista do Ministério Público do Trabalho, v.26, p.34.

${ }^{6}$ LOTTO, Luciana Aparecida. Ação Civil Pública Trabalhista contra o Trabalho Escravo no Brasil São Paulo: LTR.2008. pp. 34. vol.08, n. 03, Rio de Janeiro, 2015.pp. 1334-1368 1337
} 
espontaneamente, iludido por falsas promessas de ótimas condições de salários, mesmo que o faça em condições sub-humanas. O fato de não conseguir se desligar do seu ofício é apenas uma de suas formas de incidência.

Em observância ao princípio da legalidade, para que a sanção penal seja efetivamente aplicada, é preciso que ocorra, na prática, uma das hipóteses caracterizadoras da escravidão. O artigo 149 do Código Penal as descreve ${ }^{7}$ :

Art. 149. Reduzir alguém a condição análoga à de escravo, quer submetendo-o a trabalhos forçados ou a jornada exaustiva, quer sujeitandoo a condições degradantes de trabalho, quer restringindo, por qualquer meio, sua locomoção em razão de dívida contraída com o empregador ou preposto:

Pena - reclusão, de dois a oito anos, e multa, além da pena correspondente à violência.

$\$ 1^{\circ}$ Nas mesmas penas incorre quem:

I. cerceia o uso de qualquer meio de transporte por parte do trabalhador, com o fim de retê-lo no local de trabalho;

II. mantém vigilância ostensiva no local de trabalho ou se apodera de documentos ou objetos pessoais do trabalhador, com o fim de retê-lo no local de trabalho.

No mesmo sentido, têm-se a Instrução Normativa no 91/2011, descrevendo que trabalho análogo ao de escravo é aquele que resulte nas seguintes situações, de forma isolada ou em conjunto ${ }^{8}$ :

I. A submissão de trabalhador a trabalhos forçados;

II. A submissão de trabalhador a jornada exaustiva;

III. A sujeição de trabalhador a condições degradantes de trabalho;

IV. A restrição da locomoção do trabalhador, seja em razão de dívida contraída, seja por meio do cerceamento do uso de qualquer meio de transporte por parte do trabalhador, ou por qualquer outro meio com o fim de retê-lo no local de trabalho;

V. A vigiância ostensiva no local de trabalho por parte do empregador ou seu preposto, com o fim de retê-lo no local de trabalho;

VI. A posse de documentos ou objetos pessoais do trabalhador, por parte do por parte do empregador ou seu preposto, com o fim de retê-lo no local de trabalho.

O uso da analogia para se definir um crime não é adequado, já que amplia as formas de interpretação, favorecendo a impunidade. Deve-se, portanto, interpretar cada caso concreto com a máxima observância das hipóteses previstas no tipo penal, de forma a evitar a discricionariedade e dúvidas quanto à existência real do crime ou meras irregularidades trabalhistas 9 .

No trabalho forçado há a violação da liberdade de locomoção do trabalhador, estando o escravizado impedido de deixar o local e sendo compelido a prestar sua força de trabalho. É "toda modalidade de exploração do trabalhador em que este esteja impedido, moral, psicológica e/ou fisicamente, de abandonar o serviço, no

${ }^{7}$ Código Penal, artigo 149.

${ }^{8}$ Instrução Normativa no $91 / 2011$.

${ }^{9}$ NEVES, Débora Maria Ribeiro. Trabalho escravo e aliciamento. São Paulo: LTr, 2012, pp. 47. vol.08, nº. 03, Rio de Janeiro, 2015.pp. 1334-1368 
momento pelas razões que entender apropriadas, a despeito de haver, inicialmente, ajustado livremente a prestação de serviços ${ }^{10 "}$.

A jornada exaustiva está presente quando o trabalhador se submete a excesso de jornada, exaurindo-o e impossibilitando-o de usufruir da vida em sociedade, esgotando completamente o trabalhador e retirando sua força física e mental. É preciso diferenciar a hipótese de redução à condição análoga à de escravo da mera irregularidade no pagamento de horas suplementares. A jornada exaustiva, além de fugir das regras da CLT, que impõe limitação de até duas horas extras por dia, ou em caso de necessidade imperiosa, força maior, ou conclusão de serviços inadiáveis, até quatro horas extras ao dia, também é a jornada exercida sem remuneração, compensação ou intervalos para refeição, descanso e higiene pessoal. Ou seja, para a caracterização do crime, tão importante quanto as horas efetivamente trabalhadas, é a verificação das condições em que o trabalho foi prestado ${ }^{11}$.

O trabalho em condições degradantes é aquele em que não são respeitados os direitos mínimos dos trabalhadores, que prestam serviços em péssimas condições, sem direito a saúde, higiene, justa remuneração, segurança ou moradia digna. Sobre o tema, entende Nucci:

Degradação significa rebaixamento, indignidade ou aviltamento de algo. No sentido do texto, é preciso que o trabalhador seja submetido a um cenário humilhante de trabalho, mais compatível a um escravo do que a um ser humano livre e digno. Logo, apesar de se tratar de tipo aberto, depende, pois, da interpretação do juiz, o bom-senso está a indicar o caminho a ser percorrido, inclusive se valendo o magistrado da legislação trabalhista, que preserva as condições mínimas apropriadas do trabalho humano ${ }^{12}$.

$\mathrm{Na}$ quarta hipótese típica de escravidão, há a restrição da liberdade de locomoção dos trabalhadores e o impedimento do encerramento do contrato de trabalho em função de dívida. Sendo o trabalhador obrigado a continuar na fazenda até saldar a dívida falsa contraída. Importante destacar que o consentimento do trabalhador para trabalhar em condições degradantes até pagar a dívida não afasta o crime, pois os escravizados não possuem consciência dos seus direitos, que são inalienáveis, inegociáveis e irrenunciáveis. Sem o grau de conhecimento mínimo, não questionam a dívida que thes são exigidas e são altamente influenciáveis a ponto de acreditarem que a cobrança é permitida por lei, criando situação de total sujeição ${ }^{13}$.

Tem-se ainda as hipóteses, chamadas de trabalho escravo por equiparação, previstas no parágrafo $1^{\circ}$ do artigo 149. São formas equiparadas ao crime previsto no caput do artigo e são penalizadas com o mesmo quantum $^{14}$.

\footnotetext{
${ }^{10}$ MELO, Luís Antônio Camargo de. Revista do Ministério Público do Trabalho, v.26, p. 14.

${ }^{11}$ NEVES, Débora Maria Ribeiro. Trabalho escravo e aliciamento. São Paulo: LTr, 2012, pp.50-51.

${ }^{12}$ NUCCI, Guilherme de Souza. Código Penal Comentado. 10 ed. Ver. Atual. E ampl. São Paulo: Revista dos Tribunais, 2010. pp. 706.

${ }^{13}$ NEVES, Débora Maria Ribeiro. Trabalho escravo e aliciamento. São Paulo: LTr, 2012, pp.55.

${ }^{14}$ NEVES, Débora Maria Ribeiro. Trabalho escravo e aliciamento. São Paulo: LTr, 2012, pp. 48. vol.08, nº. 03, Rio de Janeiro, 2015. pp. 1334-1368 
As três hipóteses equiparadas possuem o mesmo objetivo, qual seja, a retenção do trabalhador no local de trabalho. Para a caracterização do crime não é preciso que ocorram de forma conjunta, isoladamente já podem configurar a escravidão. Mas para que a configuração da prática ilegal aconteça, é preciso que haja o dolo específico de reter a vítima no local de trabalho, utilizando o empregador de meios diretos ou indiretos. ${ }^{15}$

A primeira forma equiparada de escravidão é o cerceamento do uso de qualquer meio de transporte. Nessa hipótese, o empregador impede o acesso a qualquer meio de transporte, retendo o empregado na fazenda até a execução do serviço. Neste caso, o isolamento geográfico das fazendas e a ausência de transporte público dificulta a fuga e torna mais fácil a manutenção da escravidão. ${ }^{16}$

O segundo modo equiparado é a manutenção de vigilância ostensiva. Através de pessoas armadas, o empregado é coagido a permanecer na fazenda e prestar serviços compulsoriamente. Vigiado por todo o período do serviço, o escravizado é impedido de fugir do local e sofre castigos físicos e morais. Além de fiscalizar os serviços executados e impedir a fuga e o encerramento do contrato de trabalho, os vigilantes, agindo em conjunto com os "gatos", também possuem a função de impedir e dificultar a função dos Auditores-Fiscais do Trabalho, destruindo provas e ameaçando trabalhadores para evitar a denúncia. ${ }^{17}$

O apoderamento de documentos ou de objetos pessoais dos trabalhadores também é uma espécie de equiparação à escravização. O empregador retém carteira de identidade, CTPS ou documentos pessoais com o objetivo de manter o empregado na fazenda para que continue a lhe prestar serviços até saldar suas dívidas. Nesta hipótese, para a configuração do crime é preciso a retenção com o objetivo de impedir que o trabalhador deixe o local de trabalho. ${ }^{18}$

Ao se analisar o que o Brasil, atualmente, considera como trabalho em condição análoga à de escravo, percebe-se que se trata de situações onde não há a preservação da dignidade e igualdade do trabalhador. Trata-se de atos de superexploração do trabalho, da miséria e da necessidade do ser humano.

Mesmo após anos da modificação do Código Penal Brasileiro, as hipóteses ensejadoras do crime ainda não foram completamente compreendidas. Existem posicionamentos diferentes, o que acaba por beneficiar o empregador que comete este ilícito. Para alguns, houve a ampliação do bem jurídico, para outros, as mudanças representaram restrição quanto ao sujeito passivo, transformando o crime de comum para especial, já que anteriormente a norma não indicava os modos de execução e atualmente, o crime só pode restar configurado se praticado nos termos estritos do disciplinado na lei ${ }^{19}$.

\footnotetext{
${ }^{15}$ NEVES, Débora Maria Ribeiro. Trabalho escravo e aliciamento. São Paulo: LTr, 2012, pp. 48.

${ }^{16}$ NEVES, Débora Maria Ribeiro. Trabalho escravo e aliciamento. São Paulo: LTr, 2012, pp. 55.

${ }^{17}$ NEVES, Débora Maria Ribeiro. Trabalho escravo e aliciamento. São Paulo: LTr, 2012, pp. 57.

${ }^{18}$ NEVES, Débora Maria Ribeiro. Trabalho escravo e aliciamento. São Paulo: LTr, 2012, pp. 57.

${ }^{19}$ BRITO FILHO, José Claudio Monteiro de. Trabalho Decente: análise jurídica da exploração do trabalho: trabalho escravo e outras formas de trabalho indigno. 3 ed. São Paulo: LTR, 2013. pp. 66-67.
} 
Fato é que, apesar das divergências, o Brasil é reconhecido internacionalmente como referência no combate ao trabalho escravo e na adoção de um conceito de escravidão que protege a liberdade e dignidade do ser humano. O reconhecimento da existência de escravos em seu território e a ampliação das hipóteses caracterizadoras do crime são iniciativas significativas.

Porém, apesar dos esforços para o combate dessa prática, ainda temos a necessidade de maior conscientização a respeito do problema. Ter conhecimento de quem são os sujeitos mais expostos à escravização, quem são os empregadores que exploram o trabalho, saber o que já foi feito e as ações preventivas, são medidas para a erradicação do trabalho escravo. Essas questões serão abordadas adiante, pois não menos importante que saber a definição do trabalho escravo, é saber identificá-lo para o seu combate. Muito já foi feito, mas não restam dúvidas que há muito que fazer.

\section{Trabalho Escravo no Brasil Contemporâneo}

Por todos os avanços sociais conquistados ao passar dos anos e pela concepção de democracia vivida na atualidade, a ideia da escravidão ainda causa surpresa na população. Muitos entendem como incompatível uma exploração tão cruel e antiga ainda ser praticada em um sistema capitalista pós-moderno. Entretanto, a escravidão contemporânea é uma realidade mundial e não pode ser ignorada.

A exploração do homem pelo homem ainda continua nos dias atuais, porém apresenta algumas características que a difere da vivida no Brasil até 1888 e, por não ser a mesma, em regra, o termo escravidão é acompanhado por expressões que fazem referência à atualidade, como por exemplo, "semi", "branca", "contemporânea" ou "análoga". Esta última encontrada na legislação brasileira.

Não apenas o nome sofreu mudanças, o trabalho escravo teve seu conceito ampliado no país. Houve aumento nas hipóteses de incidência, não sendo mais exigível a restrição da liberdade de ir e vir para a caracterização do crime. Atualmente, o trabalho análogo à escravidão se faz presente quando os Direitos Humanos são afrontados e ocorrem graves danos às liberdades substantivas do cidadão.

O cenário atual é de grande divergência sobre o que de fato caracteriza o crime. A nomenclatura e o conceito se alternam de acordo com os interesses e posição política daquele que o utiliza. Sobre a questão, afirma Neide Esterci:

As classificações se fazem de acordo com o contexto, os critérios e as posições dos diversos atores envolvidos ou que se pronunciam em cada caso. É mais provável que entidades de defesa dos direitos humanos, representantes de organizações de trabalhadores, trabalhadores e seus advogados concordem entre si quanto à caracterização e enquadramento legal de uma situação. É provável também que discordem de representantes de órgão públicos e empregadores em virtude de suas respectivas posições na cena política. 
O fato de não termos uma caracterização jurídica uniforme, gera interpretações divergentes e beneficia a quem pratica o ilícito. Sendo um problema a ser resolvido. Porém, o ponto em comum entre as compreensões dos diversos autores que repreendem o trabalho escravo é a violação da dignidade do trabalhador. A negação dos direitos fundamentais é o elemento diferenciador em relação aos meros desrespeitos às normas trabalhistas.

\section{Principais Atores}

Existem diversos atores que contribuem para a escravidão. Os principais são o trabalhador, o empregador e o intermediário.

O trabalho escravo contemporâneo se apresenta sob diversas formas e apesar de o trabalho escravo rural ser predominante no Brasil, não se limita ao âmbito agrário e à exploração do homem em Idade Média. As vítimas, portanto, podem variar de idade, abordando o trabalho infantil, e de gênero, referindo-se à exploração sexual feminina, no tráfico de pessoas.

A coerção da criança para o desempenho de atribuições vedadas à sua idade provoca grandes danos físicos e morais. Dentre eles, podemos citar o acesso social limitado, a falta ou redução de frequência escolar, a possibilidade de assédio sexual e a falta de qualificação profissional.

No Brasil, é admitido o trabalho a partir dos 14 anos, na qualidade de aprendiz; apenas os maiores de 16 anos, podem exercer o trabalho comum (fora do processo de aprendizagem). A Constituição Federal fixa as idades da seguinte maneira: proibição de trabalho noturno, perigoso ou insalubre a menores de dezoito e de qualquer trabalho a menores de dezesseis anos, salvo na condição de aprendiz, a partir de quatorze anos. $\mathrm{O}$ Estatuto da Criança e do Adolescente acrescenta proibição de trabalhos "penosos" e realizados em locais prejudiciais à formação e ao desenvolvimento físico, psíquico, moral e social da criança.

As normas fixadoras de idade mínima para o exercício do labor buscam proteger o menor de idade da exploração econômica. Dessa forma, devem ser interpretadas na perspectiva de preservação de Direitos Humanos da criança.

O Brasil promulgou a Convenção 182 e a Recomendação 190 da OIT, sobre a proibição das piores formas de trabalho infantil e a ação imediata para sua eliminação, concluídas em Genebra, em 17 de junho de 1999.

Outra forma de escravidão é o trafico de pessoas, em regra, de mulheres para fins de exploração sexual. Encontra-se tipificado no Protocolo de Palermo ${ }^{20}$, que busca definir, prevenir e reprimir esse delito em proporção

\footnotetext{
${ }^{20}$ Protocolo para Prevenir, Eliminar e Castigar o Tráfico de Pessoas, especialmente mulheres. É um dos protocolos adicionais da Convenção das Nações Unidas contra a Delinquência Organizada Transnacional, também conhecido como Protocolo e Convenção de Palermo, por ter sido realizado em Palermo, Itália, em março de 2000. Foi adotado pela Assembleia Geral da ONU em 15 de novembro de 2000, mediante a Resolução: A/RES/55/25.
}

vol.08, nº. 03, Rio de Janeiro, 2015.pp. 1334-1368 1342 
mundial. O crime de tráfico de pessoas está inserido no âmbito do trabalho escravo por ferir a liberdade e a dignidade como pessoa, estando, a mulher explorada, em situação de semiescravidão: sujeita a maus-tratos, abuso sexual, exploração contínua e trabalhando em condição sub-humana ${ }^{21}$.

Por ser um crime que excede a jurisdição do país, exige ações conjuntas dos países fornecedores e receptores de mulheres escravizadas, dificultando sua efetiva erradicação. Constitui-se pelo recrutamento, com possível consentimento da vítima, transporte e alojamento. Os abusadores se aproveitam da vulnerabilidade da vítima, com promessa de ótimos salários e as mantém na situação com contínuas ameaças de deportação ${ }^{22}$.

O Brasil é um grande fornecedor de mulheres para exploração sexual, sendo a Espanha o principal país de destino. Mesmo com o desenvolvimento de planos nacionais contra o tráfico de mulheres nos dois países, ainda há grande carência tanto de formas de atuação e prevenção como de repreensão ao tráfico.

No âmbito nacional, a região de maior incidência de trabalhador explorado no país é no campo, incidindo, principalmente, nas regiões do norte e nordeste do Brasil. O escravizado é, em regra, vítima da exclusão social, não possuindo recursos para sustentar sua família, vivendo em condição de miséria. Buscando melhores condições, a vítima abandona seu ambiente familiar e acaba sendo atraído pelos aliciadores, com promessas de bons salários e melhoria de vida.

As fazendas se encontram em regiões distantes e desconhecidas, dificultando qualquer tentativa de fuga do escravizado, que também não possuem informações e instruções suficientes a fim de não aceitarem a submissão. O trabalhador rural escravizado é o excluído socialmente, em situação de alta vulnerabilidade com problemas econômico e dificilmente profissionalizado para conseguir um emprego digno e justo. ${ }^{23}$

O empregador, em regra, empresário fazendeiro, contrata os trabalhadores por intermédio dos chamados "gatos". Dessa forma, por utilizar mão de obra terceirizada, acreditam estar isentos de qualquer responsabilidade trabalhista. $\mathrm{O}$ tomador de serviços não cumpre as obrigações impostas na lei, imputando responsabilidade ao fornecedor de mão de obra. Porém, estão presentes todos os requisitos para que os explorados sejam considerados empregados do fazendeiro e a terceirização ilícita, existindo subordinação e pessoalidade na prestação dos serviços.

\footnotetext{
${ }^{21}$ Trabalho escravo contemporâneo: Um debate transdisciplinar / Ricardo Rezende Figueira, Adonia Antunes Prado, Horácio Antunes de Sant'Ana Júnior, organizadores. Rio de Janeiro: Mauad X, 2011.pp. 195-209.

${ }_{22}^{2}$ Trabalho escravo contemporâneo: Um debate transdisciplinar / Ricardo Rezende Figueira, Adonia Antunes Prado, Horácio Antunes de Sant'Ana Júnior, organizadores. Rio de Janeiro: Mauad X, 2011.pp. 195-209.

${ }^{23}$ BRITO FILHO, José Claudio Monteiro de. Trabalho Decente: análise jurídica da exploração do trabalho - trabalho escravo e outras formas de trabalho indigno. Edição 2. São Paulo: LTR, 2010, pp. 68.
} 
O intermediador presta serviços para o empregador dos escravos. Sua principal função é aliciar os trabalhadores e leva-los diretamente para a fazenda, mas, também, faz serviços suplementares, possuindo certo poder de mando, podendo ficar responsável pela produção e vigilância do local de trabalho.

O homem migrante, que abandona a família, que não possui estudos e boa situação econômica é, geralmente, o perfil abordado pelo intermediador. À vista disso, o empregado é seduzido e convencido a viajar e trabalhar na fazenda, com proposta de bom salário e com perspectiva da melhoria de vida. O aliciamento é o momento em que se inicia a exploração, os gastos da viagem e possíveis adiantamentos aos trabalhadores já são considerados como dívidas. Destarte, antes mesmo de chegar ao local de trabalho, o empregado já está endividado com o futuro empregador.

Os "gatos", motivados pelo parágrafo único do artigo 442 da CLT, criam cooperativas, visto que o próprio ordenamento jurídico afirma que não há formação de vínculo empregatício entre os sócios cooperados e nem entre esses e os tomadores de serviços. Dessa forma, na terceirização encontraram a forma de fraudar a própria lei, não assumindo o tomador as responsabilidades trabalhistas pelos serviços prestados. Por sorte, a jurisprudência brasileira pune de forma rigorosa quem se utiliza da terceirização ilícita para transferir obrigações trabalhistas.

Outros atores coadjuvantes também participam do ciclo da escravidão, como os donos de pensões e os vigilantes. Os donos de pensão, muitas vezes possuem acordo com os intermediadores e fazendeiros, facilitando o aliciamento de trabalhadores que se instalam em suas pensões em busca de trabalho, muitos esperam pelo próprio "gato". Os vigilantes trabalham na fazenda do empregador, fiscalizam, aplicam castigos físicos, coagem os trabalhadores para manter o ritmo da produção e impedem as fugas.

Importante ressaltar que, apesar de toda farsa e declarações de desconhecimento acerca do modo de produção na própria fazenda, é do empregador a responsabilidade trabalhista e penal acerca do tratamento dado ao prestador de mão de obra. O que ocorre é a contratação terceirizada para o desenvolvimento de atividade-fim, com subordinação e pessoalidade, caracterizando relação direta de emprego com o fazendeiro e não com o "gato", representante deste.

\section{ASPECTOS DA ANTIGA E ATUAL ESCRAVIDÃO}

Ao compararmos a escravidão no Brasil colonial e a contemporânea, percebem-se diversos aspectos em comum, mas também, constata-se que a exploração do homem se modificou ao passar dos anos, se tornando ilegal, sutil e dissimulada.

No Brasil colonial, o modelo de produção era baseado em três aspectos: a monocultura, o latifúndio e a escravidão. Hoje, percebemos que a agroexportação cedeu seu lugar ao modelo subdesenvolvido industrializado. 
Entretanto, mesmo subordinada à indústria, a agricultura ainda carece de mão de obra humana e barata, sendo largamente utilizada a análoga ao trabalho escravo.

Podem-se considerar, como fatores comuns entre a escravidão antiga e a atual: os personagens envolvidos, a forma de manutenção de poder e as condições de trabalho. Já a diferença entre as explorações, podem ser feitas sob diversos aspectos, como: legalidade, custo, temporalidade e importância da etnicidade.

O senhor de engenho e o feitor se tornaram o fazendeiro empresário e o intermediador, respectivamente. Continuam agindo da mesma forma para manter o poder, através do uso da força. Por meio de agressões e punições, o escravo é ameaçado e coagido a permanecer no local de trabalho, em ambas as épocas, em condições sub-humanas. Não há higiene, segurança ou água potável. O índice de doença e de morte é elevado, pois estão situados em lugares de difíil localização, não tendo acesso a tratamento médico.

A maior diferença entre a escravidão colonial e a contemporânea é encontrada na norma jurídica. Anteriormente, reduzir os negros africanos a meros escravos com o objetivo de cristianizá-los era permitido pelo regulamento português, através das ordenações manuelinas ${ }^{24}$. A partir de meados do século XVI até meados do século XIX, o homem explorou e provocou a migração forçada de milhares de negros para o Brasil, de forma legal, de acordo com a lei. Hoje em dia, a exploração de um homem pelo outro é ilegal, não apenas no Brasil, é uma prática repudiada internacionalmente.

Outra diferença importante a ser ressaltada é a fonte de escravizados nos períodos de exploração. A principal mão de obra escrava utilizada no período colonial era a negra, vinda do continente africano. Os escravos eram transportados em grandes navios de carga, sem nenhuma condição humana. Eram amontoados e entregues à própria sorte, convivendo com doentes e mortos. A sua chegada com vida no Brasil era algo incerto. Nos dias atuais, os empregadores escravizam o seu próprio povo. Não há viagens interacionais, ocorrendo migrações internas. No próprio território nacional, as vítimas se deslocam principalmente do Nordeste para a região Norte, onde são aliciadas pelos "gatos" para as distantes fazendas do interior.

No período colonial, o escravo custava muito caro. A importação do negro significava grande investimento para o senhor de engenho, que recuperava todo o dinheiro gasto e ainda lucrava com a produção da mão de obra empregada. No Brasil contemporâneo, o custo para se obter um escravo é muito baixo. O dinheiro gasto é apenas em eventual adiantamento ao trabalhador no momento do aliciamento. Outrora, o empregador recupera o dinheiro transformando-o em dívida e lucra com a produção da fazenda e o não pagamento dos salários e outros benefícios devidos ao trabalhador.

Anteriormente, como a aquisição era mais onerosa, o explorado se tornava integrante do patrimônio do senhor de engenho, tornando a relação escravo-escravocrata longa, poderia durar por toda a vida. Hoje em dia,

${ }^{24}$ Considerados como primeiro corpo legislativo utilizado em Portugal, eram utilizados na administração do Reino na era dos descobrimentos do Novo Mundo. 
com grande oferta de mão de obra e o baixo custo aquisitivo, o escravo é tratado como descartável, sendo substituído, em regra, ao final de cada empreitada.

Por fim, pode-se citar a etnicidade como fator de diferenciação entre a escravidão antiga e a atual. No Brasil, a partir do século XV, comercializavam-se legalmente negros africanos e índios americanos. Destarte, a escravidão era baseada na raça a qual pertencia o ser humano. Nos dias atuais, o empregador escraviza o seu próprio povo, não sendo mais a etnia fator preponderante para a exploração.

Os excluídos socialmente e em condição de miséria são, atualmente, as vítimas da escravidão. Entretanto, existem outros fatores que contribuem e os tornam vulneráveis para o aliciamento. Como exemplos, citam-se a falta de fiscalização, o a pobreza, a distância da família e o isolamento do local de exploração e a insuficiente proteção social desenvolvida pelo Estado.

Percebe-se, portanto, que a escravidão, mesmo contemporânea, apresenta causas com origem no passado, desenvolvidas com o modelo de produção colonial e outras, atuais, que eclodiram com o desenvolvimento capitalista.

As principais causas do trabalho escravo atual são: A grande concentração de terra, a pobreza, baixa escolaridade, falta de proteção social desenvolvida pelo Estado, a falta de alternativa de renda, falta de fiscalização, incerteza quanto ao seu conceito jurídico (dificuldade de provar o crime) e distância do local da prestação de serviço.

Os fatores que contribuem para a persistência do trabalho escravo estão interligados, sendo causas ou consequências entre si, formando um ciclo de difícil interrupção.

Contudo, é inquestionável que a pobreza é a principal causa do trabalho escravo contemporâneo. Os trabalhadores têm em comum a origem pobre, a falta de escolaridade e de capacitação, o que os leva à situação de extrema pobreza e de fácil aliciamento para a prestação ilegal de mão de obra. A exclusão social os torna vulneráveis, já que a oferta de trabalho e de bom salário proposta pelos "gatos", muitas vezes, é a única oportunidade que conseguem para melhorar de vida. ${ }^{25}$

A falta de proteção social é um fator essencial para a persistência dessa prática, já que as oportunidades de melhoria de vida da população estão ligadas às ações do Estado. O combate da escravidão não é devido apenas pela ética, mas também por normas jurídicas que devem ser respeitadas e cumpridas pelo Poder Público. ${ }^{26}$

A utilização de mão de obra compulsória fere os direitos fundamentais e humanos que, de acordo com o direito internacional, os Estados possuem a obrigação de respeitar. A proteção dos direitos inalienáveis por parte da Administração Pública pode se dar de maneira preventiva, ou seja, através de políticas públicas, como a criação

\footnotetext{
${ }^{25}$ NEVES, Débora Maria Ribeiro. Trabalho escravo e aliciamento. São Paulo: LTR, 2012, pp. 115.

${ }^{26}$ Trabalho escravo contemporâneo: Um debate transdisciplinar / Ricardo Rezende Figueira, Adonia Antunes Prado, Horácio Antunes de Sant’Ana Júnior, organizadores. Rio de Janeiro: Mauad X, 2011.pp. 201-239.
} 
de empregos e programas de capacitação. Com a melhoria da qualidade de vida, a desigualdade social diminui, escasseando o aliciamento para o trabalho escravo, tornando as propostas dos intermediadores desinteressantes e desnecessárias para o trabalhador. ${ }^{27}$

A oferta de educação e trabalho, não apenas combate o trabalho escravo, mas também gera desenvolvimento econômico e justiça social.

A incerteza quanto ao seu conceito jurídico aliado à falta de fiscalização torna a punição ao escravizador irrisória, incentivando o uso da mão de obra ilegal. Não existindo um consenso sobre as práticas que configuram o trabalho análogo ao de escravo, a comprovação da existência do crime se torna ainda mais difícil e a aplicação na norma jurídica pouco utilizada.

Outro fator para a persistência da escravidão é a localização das fazendas. O lugar, geralmente, é de difícil acesso e encontra-se a grandes quilômetros de distância da civilização. $\mathrm{O}$ ambiente isolado impede as fugas e dificulta a fiscalização, que já é feita de modo insuficiente. Não há preparo ou segurança para os fiscais. A dificuldade de comunicação, aliada a falta de recursos e às ameaças constantes contra fiscais, juízes e procuradores ou a possíveis denunciadores, torna um ambiente favorável para que os aliciadores e empregadores continuem a explorar a prestação de serviços de pessoas em condições sub-humanas e saírem impunes.

Percebe-se que há consenso no sentido de que a causa da exploração humana não se explica por unicausalidade. Diversos fatores combinados propiciam a escravidão. Atualmente, o interesse econômico é o motivador dessa prática. Tanto por parte dos empresários, que anseiam obter lucros exorbitantes diminuindo os gastos com a produção, como o não pagamento dos direitos trabalhistas e por parte dos trabalhadores, que, em situação de extrema pobreza, recorrem aos trabalhos oferecidos pelos intermediadores, como meio de sobrevivência e ganho de poucos recursos para sustentar a família.

\section{LEGISLAÇÃO}

As Constituições brasileiras sempre previram direitos aos cidadãos. Dependendo de cada período histórico, detinham maiores ou menores amplitudes. Com a redemocratização, a Constituição de 1988 passou a prever detalhadamente e com grande número de dispositivos os direitos e garantias fundamentais. ${ }^{28}$

Sobre a nova Constituição e a conquista de diversas garantias constitucionais, preceitua Luís Roberto Barroso:

Sob a Constituição de 1988, aumentou de maneira significativa a demanda por justiça social na sociedade brasileira. Em primeiro lugar, pela redescoberta da cidadania e pela conscientização das pessoas em

\footnotetext{
${ }^{27}$ Trabalho escravo contemporâneo: Um debate transdisciplinar / Ricardo Rezende Figueira, Adonia Antunes Prado, Horácio Antunes de Sant'Ana Júnior, organizadores. Rio de Janeiro: Mauad X, 2011.pp. 201-239.

${ }^{28}$ NEVES, Débora Maria Ribeiro. Trabalho escravo e aliciamento. São Paulo: LTR, 2012, pp. 26. vol.08, nº. 03, Rio de Janeiro, 2015.pp. 1334-1368 
relação aos próprios direitos. Em seguida, pela circunstância de haver o texto constitucional criado novos direitos, introduzindo novas ações e ampliando a legitimação ativa para tutela de interesses, mediante representação ou substituição processual ${ }^{29}$.

Importante destacar que a Constituição não abrange apenas o campo formal. Há, na própria norma, a exigência de efetiva prestação do Estado para garantia dos direitos tutelados, que possuem eficácia e aplicabilidade imediata, devendo o Poder Público assegurar o pleno exercício das garantias constitucionais e indenizar o cidadão quando houver desrespeito às normas ${ }^{30}$.

Dessa forma, a Carta Magna é a principal norma jurídica brasileira para garantir direitos fundamentais e protegê-los de serem violados, sendo a base de legitimação para a criação das normas infraconstitucionais. ${ }^{31}$

Além da ética e da consciência humana, o combate ao trabalho escravo se justifica por ir de encontro a todo o ordenamento jurídico brasileiro.

Como Estado Social, a Constituição Federal de 1988, em seu artigo $1^{\circ}$, incisos III e IV, preceitua que seus fundamentos são, dentre outros, a dignidade da pessoa humana e os valores sociais do trabalho e da livre iniciativa. Apenas em um artigo da Constituição, a prática de escravizar outro ser humano já é caracterizada como ilegal, pois fere o direito do homem por ser cidadão, constituidor de direitos e dever perante a sociedade e viola, também, o valor social do trabalho, que se justifica por garantir ao homem sustento e melhoria de vida.

Os dispositivos seguintes, não menos que o primeiro, rechaçam a possibilidade de tratamento subhumano a um cidadão. Como exemplo, o artigo $3^{\circ}$ traz os objetivos fundamentais da República, que são, dentre eles, construir uma sociedade livre, justa e solidária (inciso I), erradicar a pobreza e a marginalização e reduzir as desigualdades sociais e regionais (inciso III) e promover o bem de todos, sem preconceitos de origem, raça, sexo, cor, idade e quaisquer outras formas de discriminação (inciso IV).

A condição de um ser com garantias de direitos é negada ao trabalhador escravo, sendo coagido a prestar serviços em condições degradantes e sob ameaça, sem direito a nenhuma prestação garantida pelo Estado. São cidadãos que vivem no território de jurisdição das normas sociais, porém que não os alcança. Vivem sob domínio e lei do próprio empregador, discriminados em função da condição econômica e social.

Os parágrafos segundo, terceiro e quarto da Constituição Federal afirmam que o Brasil pode reconhecer direitos e tratados internacionais sem, contudo, excluir os princípios e garantias adotados pelo país. Assim, os tratados internacionais sobre direitos humanos, aprovados, em cada Casa do Congresso Nacional, em dois turnos, por três quinto dos votos, serão equivalentes às emendas constitucionais. Aplicam-se sanções ao empregador que adotar o trabalho escravo, além das normas brasileiras, as previstas no cenário internacional adotadas pelo país.

\footnotetext{
${ }^{29}$ BARROSO, Luís Roberto. Curso de Direito Constitucional Contemporâneo: Os conceitos fundamentais e a construção do novo modelo. 2.Ed.São Paulo; Saraiva, 2010. P. 384.

${ }^{30}$ NEVES, Débora Maria Ribeiro. Trabalho escravo e aliciamento. São Paulo: LTR, 2012, pp. 24 - 27.

${ }^{31}$ NEVES, Débora Maria Ribeiro. Trabalho escravo e aliciamento. São Paulo: LTR, 2012, pp. 24-27.
} vol.08, n. 03, Rio de Janeiro, 2015.pp. 1334-1368 
$\mathrm{O}$ artigo $5^{\circ}$ elenca os direitos e deveres individuais e coletivos garantidos pelo Estado a todos os brasileiros e residentes no país, dentre eles, vida, liberdade, segurança, igualdade e propriedade.

O direito a propriedade deve ser interpretado juntamente com os princípios da função social e valorização do trabalho humano ${ }^{32}$. A sua violação indica concentração de terra e falta de produtividade na propriedade, características que podem estar diretamente ligadas ao trabalho escravo. Vejamos:

Intrinsecamente associada à pobreza, a questão da concentração de terras - que afeta o Brasil como um todo e particularmente os Estados de origem de trabalhadores rurais em situações de escravidão - é também uma causa estrutural do trabalho escravo. Ela exacerba a pobreza, pois os trabalhadores são privados do principal recurso que os permitiria sustentar-se em áreas rurais, qual seja, terra. Sem terra, a renda do trabalhador, normalmente baixa, torna-se seu esteio em termos de sobrevivência.

Sem terras, desempregados (...) buscam oportunidades de emprego nas regiões norte e nordeste do Brasil. Tais condições criam alta vulnerabilidade para esses trabalhadores, levando-os a aceitar condições de trabalho degradantes ${ }^{33}$.

O direito a propriedade, sua função social e os valores do trabalho são violados em terras onde trabalham pessoas em condições análogas ao escravo, porque desrespeita o trabalho humano e nega a própria condição humana, digna de direitos e de proteção, além de ignorar as normas e o Estatuto da Terra (Lei n. 4.504/1964) e retirar do discriminado sua fonte e alimento e renda ${ }^{34}$.

O artigo 184 da Constituição Federal autoriza a desapropriação de terra para fins de reforma agrária, mediante prévia e justa indenização. Porém, apesar da medida preservar o interesse social, não reprime o trabalho escravo. Nesse contexto, foi criada uma PEC, no Senado Federal, com o objetivo de alterar o artigo 423 da CR/88 e prever a expropriação de terras onde forem encontradas culturas de plantas psicotrópicas e as propriedades flagradas com utilização de mão de obra escrava.

Apesar de grupos bem organizados no Congresso serem contra sua aprovação, como a bancada ruralista, a PEC n. 438/2001 foi aprovada no Senado Federal. Considerado "um momento histórico". A aprovação da PEC representa um grande avanço no combate à escravidão contemporânea, já que propicia uma pena mais rígida para os empregadores que adotam a prestação de serviço escrava.

O artigo $5^{\circ}$, inciso III, veda a submissão à tortura e ao tratamento desumano ou degradante, que são práticas impostas ao trabalhador escravo.

\footnotetext{
${ }^{32}$ NEVES, Débora Maria Ribeiro. Trabalho escravo e aliciamento. São Paulo: LTR, 2012, pp. 28-29.

${ }^{33}$ ORGANIZAÇÃO DAS NAÇÕES UNIDAS. Reporto f the special rapporteur on coontemporary forms of slavery, including its causes and consequences, Gulnara Shahinian: Mission to Brazil. Disponível em:<www2.ohchr.org/English/bodies/hrcouncil/docs/15session/A.HRC.15.20..Add.4_en.pdf>.

${ }^{34}$ NEVES, Débora Maria Ribeiro. Trabalho escravo e aliciamento. São Paulo: LTR, 2012, pp. 28-29. vol.08, nº. 03, Rio de Janeiro, 2015.pp. 1334-1368 
A proibição da prisão civil por dívida, o livre exercício de qualquer trabalho e a livre locomoção no território nacional (artigo 5, LXVII, XIII e XV da CCR/88), também são igualmente violados.

Os artigos $6^{\circ}$ e $7^{\circ}$, situados no capítulo III, Dos Direitos Sociais, da Carta Magna, são completamente ignorados no regime de escravidão. São normas de ordem pública, portanto, inalienáveis e irrenunciáveis, sendo o mínimo de direitos existenciais para o trabalhador ${ }^{35}$.

Estes artigos asseguram direitos conquistados ao longo da história, como: seguro-desemprego, fundo de garantia por tempo de serviço, salário mínimo, décimo terceiro, férias, tempo máximo de jornada, licença gestante, aviso prévio, redução dos riscos inerentes ao trabalho, por meio de normas de saúde, higiene e segurança e aposentadoria.

E conforme preceitua o artigo 193 da Constituição, o trabalho e a justiça social constituem a ordem social, sendo de interesse público e dever do Estado a garantia de todos os direitos aos brasileiros, buscando a igualdade social.

Insta ainda mencionar que, no regime de escravidão, não apenas a Constituição Federal é violada. A Consolidação das Leis do Trabalho e as Normas Reguladoras do Ministério do Trabalho (NR'S) estão entre as normas legais previstas no ordenamento jurídico brasileiro que são descumpridas.

Neste particular, é digno de nota que a mera violação dos direitos trabalhistas não caracteriza, por si só, o trabalho escravo. É preciso que estejam presentes os elementos ensejadores do crime. A prisão por dívida e a condição degradante, dentre outros, devem estar presentes, em conjunto ou isoladamente, no ambiente da prestação de serviço.

Entretanto, faz-se necessário analisar os diversos dispositivos previstos na CLT que coíbem o trabalho escravo. Desde o aliciamento, durante o contrato e até a dispensa do trabalhador em condição análoga à de escravo, há a violação de direitos garantidos aos brasileiros.

Imprescindível destacar que o consentimento do trabalhador não é requisito para caracterizar o crime, pois são violados direitos irrenunciáveis. Em regra, o empregado aceita as condições a que será submetido por não ter outro modo de sobrevivência.

A terceirização usada como recrutamento de mão de obra é ilegal. Estão presentes os elementos caracterizadores da relação de emprego com o tomador. Como há a prestação de serviços sobre a atividade fim das fazendas, existe o vínculo empregatício com trabalhador aliciado, devendo o fazendeiro ser responsabilizado por todos os direitos trabalhistas devidos.

${ }^{35}$ NEVES, Débora Maria Ribeiro. Trabalho escravo e aliciamento. São Paulo: LTR, 2012, pp. 33. 
O trabalhador ao chegar à fazenda geralmente é iniciado logo após a apreensão dos documentos e a notificação da dívida gerada pelo transporte e comida utilizados, impedindo os trabalhadores de deixarem o local e já os tornando prisioneiros.

O artigo 13 da CLT, afirma que:

A Carteira de Trabalho e Previdência Social é obrigatória para o exercício de qualquer emprego, inclusive de natureza rural, ainda que em caráter temporário, e para o exercício por conta própria de atividade profissional remunerada ${ }^{36}$.

Os trabalhadores aliciados não possuem carteira de trabalho assinada, sequer têm o vínculo de emprego reconhecido. Isso reflete em diversos outros dispositivos da norma, como o não recolhimento previdenciário e o descumprimento do artigo 41 da CLT, já que não há registro dos trabalhadores no local da prestação de serviço.

A CLT destina todo um capítulo para tratar sobre o tema de segurança e medicina do trabalho (Capítulo V), assunto também previsto na CR/88 no art. $7^{\circ}$, inciso XXII. Contudo, o trabalhador em condições análogas à de escravo não é equipado de forma adequada ao ambiente de trabalho. Botas, viseiras, máscaras e chapéus, necessários aos serviços, especialmente quando prestados debaixo do sol quente ou quando se opera motosserras, não são utilizados. E quando os são, os preços dos equipamentos convertem-se em dívidas dos trabalhadores, cobrados acima da média do mercado. As leis trabalhistas preveem que o custo do equipamento fica a cargo do empregador, sem descontos nos salários, senão por lei, adiantamento ou de contrato coletivo.

As condições degradantes a que estão submetidos os empregados são flagrantes. Em geral, não há água potável, higiene ou ambiente saudável de trabalho, os alojamentos são precários e sem segurança e a comida insuficiente e sem qualidade.

Dessa forma, com as condições de trabalho perigosas e insalubres, as Normas Reguladoras n ${ }^{\circ} 15$ e 16, garantem o recebimento dos respectivos adicionais aos trabalhadores ao listar elementos existentes nas fazendas, como exposição ao frio, calor e contato com agentes químicos e inflamáveis que ensejam a percepção dos referidos adicionais ${ }^{37}$.

A NR 21 disciplina as atividades prestadas a céu aberto e exige medidas especiais para proteger o obreiro, como a existência de abrigos e o fornecimento de alojamentos em condições sanitárias adequadas, sendo vedada a moradia coletiva de famílias ${ }^{38}$.

As Normas Reguladoras são diariamente descumpridas. Os adicionais devidos além de não serem pagos, na prática, diversas dívidas são ilegalmente descontadas dos empregadores, que dormem em ambientes coletivos, sem condições sanitárias dignas e sem privacidade. Os empregados vivem de maneira sub-humana e são explorados ao limite pelo fazendeiro.

\footnotetext{
${ }^{36}$ Artigo 13 da Consolidação das Leis do Trabalho.

${ }^{37}$ NEVES, Débora Maria Ribeiro. Trabalho escravo e aliciamento. São Paulo: LTR, 2012, pp. 94.

${ }^{38}$ NEVES, Débora Maria Ribeiro. Trabalho escravo e aliciamento. São Paulo: LTR, 2012, pp. 95. vol.08, n. 03, Rio de Janeiro, 2015.pp. 1334-1368
} 
Sobre a jornada de trabalho há total desrespeito às limitações vigentes nas normas. Conforme os artigos 58 e 59 da CLT, a duração do trabalho não deverá exceder 8 (oito) horas diárias e 44 (quarenta e quatro) semanais. Mediante acordo, a jornada poderá ser acrescida de 2 (duas) horas até 4 (quatro), em situações excepcionais, sempre comunicadas ao devido órgão e pagas em quantia superior à da hora normal.

Em relação aos intervalos, o interjornada estabelece, nos artigos 66 e 67 da CLT, o período mínimo de 11 (onze) horas consecutivas para descanso entre as jornadas e de 24 (vinte e quatro) horas consecutivas para descanso semanal. $\mathrm{O}$ artigo 71 dispõe sobre a intrajornada, estabelecendo o intervalo para repouso e alimentação mínimo de 1 (uma) hora quando a duração do trabalho exceder 6 (seis) horas e de 15 (quinze) minutos quando a duração não exceder 6 (seis) e ultrapassar 4 (quatro) horas.

Apesar de a norma limitar as horas diárias e semanais de serviço, a vítima da escravidão cumpre jornadas exaustivas, superiores não apenas ao estabelecido em lei, mas também ao próprio limite físico, ocorrendo indisposições, desmaios ou até mesmo morte. $\mathrm{O}$ excesso de jornada também reduz ou torna inexistente a convivência com família e amigos, acarretando graves danos físicos e psicológicos.

O regime da escravidão utiliza o ganho por produção, estimulando o próprio obreiro a exceder o limite da jornada. A remuneração do trabalhador está proporcionalmente ligada a sua produção. Ou seja, quanto maior a quantidade de horas trabalhadas, maior será seu ganho, que, por sua vez, é menor que o mínimo necessário à efetivação dos seus direitos.

Além disso, o local da prestação de serviço descumpre o sistema de ponto, exigido pela CLT em seu artigo $74, \$ 2^{\circ}$ da CLT, que objetiva o controle da jornada em estabelecimentos com mais de dez trabalhadores.

As promessas de bons salários e a expectativa de melhoria de vida são apenas falsos atrativos utilizados para o aliciamento. O obreiro, que deveria receber o mínimo salário, disposto no artigo 7o, IV da Constituição e artigo 76 da CLT, capaz de satisfazer as necessidades básicas, como alimentação, habitação, vestuário, higiene e transporte, não recebe o suficiente para assegurar seus direitos e garantir o sustento da sua família.

Por vezes, o empregador desconta dívidas fraudulentas geradas no decorrer da prestação de serviço, podendo ultrapassar o valor do salário devido ao empregado, caracterizando a escravidão por dívida ${ }^{39}$, descumprindo o artigo $462 \mathrm{da}$ CLT.

O artigo 82, parágrafo único, da CLT, estabelece o pagamento do salário em dinheiro não inferior a $30 \%$ do salário mínimo fixado para a região. Ocorre que os salários, quando pagos, são convertidos em salário in natura acima do limite permitido, na forma de aquisições de produtos nos barracões das próprias fazendas, provocando o endividamento cada vez maior do trabalhador e violando o artigo $462, \$ 2^{\circ}$, da CLT, que veda a empresa a exercer coação ou induzimento para que os empregados utilizem produtos do armazém.

\footnotetext{
${ }^{39}$ Lotto, Luciana Aparecida. Ação civil pública trabalhista contra o trabalho escravo no Brasil. São Paulo: Ltr, 2008. Pp. 55.
} vol.08, nº. 03, Rio de Janeiro, 2015.pp. 1334-1368 
Durante toda a relação contratual há descumprimento das normas trabalhistas e no seu término, quando o trabalhador é dispensado sem justa causa, as violações permanecem. O aviso prévio, assegurado pela Constituição Federal em seu artigo $7^{\circ}$, I e XXI e pela CLT, artigo 487, é uma indenização que objetiva a manutenção da subsistência do obreiro no tempo hábil de conseguir outra fonte de sustento, porém, o trabalhador escravizado, quando dispensado pelo empregador, não recebe nenhuma verba indenizatória, bem como o $13^{\circ}$ salário, previsto na Lei no 4090/1962, na Lei no 4749/1965, e no artigo 7o, inciso VIII da CRFB/88 com o objetivo de reforçar o poder de compra do trabalhador, não é auferido.

O FGTS, regido pela Lei no 8036/1990 e artigo 7º inciso III da CRFB/88, é definido pelo Ministério do Trabalho e Emprego como a formação de um pecúlio a ser recebido quando da demissão, com o objetivo de proteger o trabalhador contra despedidas sem justa causa e as contribuições previdenciárias, Lei no 8212/1991 e artigo 195, inciso I da CRFB/88, não são recolhidos em prol do escravizado. Dessa forma, quando dispensados, não possuem nenhuma garantia e fonte de subsistência.

Conforme exposto, as normas trabalhistas são ignoradas e descumpridas desde o aliciamento até a dispensa, em total desrespeito pela dignidade humana e direitos mínimos do trabalhador.

O trabalho escravo é também uma conduta criminosa, desde a promulgação do Código Penal de 1940 (Decreto-Lei n. 2.848 de dezembro de 1940), passando a vigorar em 1942. O artigo 149 previa somente que reduzir alguém à condição análoga à de escravo estava sujeito à pena de reclusão de dois a oito anos ${ }^{40}$.

A incriminação era vaga e indeterminada, o que dificultava o reconhecimento da prática do crime pelas autoridades trabalhistas e penais, pois não se sabia ao certo se era trabalho escravo ou meras irregularidades administrativas e com isso, impedia a punição dos criminosos.

A Lei no 10.803, de 11 de dezembro de 2003, alterou o artigo 149 do Código Penal, indicando as hipóteses caracterizadoras do crime com a seguinte redação:

Art. 149. Reduzir alguém a condição análoga à de escravo, quer submetendo-o a trabalhos forçados ou a jornada exaustiva, quer sujeitandoo a condições degradantes de trabalho, quer restringindo, por qualquer meio, sua locomoção em razão de dívida contraída com o empregador ou preposto:

Pena - reclusão, de dois a oito anos, e multa, além da pena correspondente à violência.

$\mathbb{S} 1^{\circ}$ Nas mesmas penas incorre quem:

I - cerceia o uso de qualquer meio de transporte por parte do trabalhador, com o fim de retê-lo no local de trabalho;

II - mantém vigilância ostensiva no local de trabalho ou se apodera de documentos ou objetos pessoais do trabalhador, com o fim de retê-lo no local de trabalho.

$\$ 2^{\circ}$ A pena é aumentada de metade, se o crime é cometido:

I - contra criança ou adolescente;

${ }^{40}$ NEVES, Débora Maria Ribeiro. Trabalho escravo e aliciamento. São Paulo: LTR, 2012, pp. $42-43$. 
II - por motivo de preconceito de raça, cor, etnia, religião ou origem ${ }^{41}$.

A redação atual adotada pela legislação Brasileira tutela o bem jurídico da dignidade da pessoa humana, não sendo mais exigido o cerceamento da liberdade física para restar configurado o crime.

O trabalho forçado existe quando o trabalho escravo é prestado de forma compulsória, quando não há liberdade de ir e vir. A jornada exaustiva ultrapassa o limite legal de jornada de trabalho, exaurindo o trabalhador. O trabalho em condições degradantes é encontrado quando o serviço é prestado sem o mínimo de higiene, saúde, segurança e alimentação e por fim, a restrição por locomoção em razão de dívida contraída é a servidão por dívida, o cerceamento da liberdade do obreiro em razão de dívida fraudulenta ${ }^{42}$.

Apesar de a inovação ter restringido a aplicabilidade, apenas podendo ser constatado se presentes as hipóteses previstas no artigo, a lei de 2003 detalhou o tipo penal, diminuindo as dúvidas de interpretação e conferindo maior grau de certeza na constatação do crime ${ }^{43}$.

O crime não existe na modalidade culposa, trata-se de crime culposo, permanente e admite-se a tentativa, não sendo necessário o consentimento da vítima por violar direitos fundamentais irrenunciáveis ${ }^{44}$.

A alteração não modificou a pena, mas estabeleceu cumulação com multa e com a pena do crime correlato e a majoração da pena se praticado contra criança ou adolescente ou por preconceito de raça, cor, etnia, religião ou origem.

O ordenamento jurídico brasileiro adequou o crime de reduzir alguém à condição análoga à de escravo ao contexto atual, descrevendo suas hipóteses e diminuindo incertezas, porém é preciso que haja um Judiciário eficaz na aplicação das sanções e prisões dos escravizadores contemporâneos, já que atualmente raros são os efeitos da norma em casos concretos, estimulando a reincidência e impunidade ${ }^{45}$.

Neste particular, o artigo 109, da Constituição Federal de 1998 estabelece como casos da competência federal, dentre outros, as causas em que a União, entidade autárquica ou empresa pública federal forem interessadas, os crimes contra a organização do trabalho e as causas que atentam contra os direitos humanos em geral. Sendo fundamento de competência federal, visto que o trabalho em condições análogas à de escravo é um crime contra o trabalho e contra a dignidade da pessoa humana, sendo de interesse da coletividade.

Contudo, até os dias atuais, ainda há insegurança e incerteza acerca dessa competência constitucional. A problemática se estende por décadas e no julgamento do RE 398.041, o Supremo Tribunal Federal concedeu a competência da Justiça federal para julgar os crimes de redução à condição análoga à de escravo:

Direito penal e processual penal. Art. 149 do Código Penal. Redução á condição análoga à de escravo. Trabalho escravo. Dignidade da pessoa

\footnotetext{
${ }^{41}$ Artigo 149 do Código Penal.

${ }^{42}$ NEVES, Débora Maria Ribeiro. Trabalho escravo e aliciamento. São Paulo: LTR, 2012, pp. $42-43$.

${ }^{43}$ NEVES, Débora Maria Ribeiro. Trabalho escravo e aliciamento. São Paulo: LTR, 2012, pp. 44-45.

${ }^{44}$ NEVES, Débora Maria Ribeiro. Trabalho escravo e aliciamento. São Paulo: LTR, 2012, pp. 44-45.

${ }^{45}$ NEVES, Débora Maria Ribeiro. Trabalho escravo e aliciamento. São Paulo: LTR, 2012, pp. 43-46.
} vol.08, n. 03, Rio de Janeiro, 2015.pp. 1334-1368 
humana. Direitos fundamentais. Crime contra a coletividade dos trabalhadores. Art. 109, VI da Constituição Federal. Competência. Justiça federal. Recurso extraordinário provido.

A Constituição de 1988 traz um robusto conjunto normativo que visa à proteção e efetivação dos direitos fundamentais do ser humano.

A existência de trabalhadores a laborar sob escolta, alguns acorrentados, em situação de total violação da liberdade e da autodeterminação de cada um, configura crime contra a organização do trabalho.

Quaisquer condutas que possam ser tidas como violadoras não somente do sistema de órgãos e instituições com atribuições para proteger os direitos e deveres dos trabalhadores, mas também dos próprios trabalhadores, atingindo-os em esferas que lhes são mais caras, em que a Constituição thes confere proteção máxima, são enquadráveis na categoria dos crimes contra a organização do trabalho, se praticadas no contexto das relações de trabalho.

Nesses casos, a prática do crime prevista no art. 149 do Código Penal (Redução à condição análoga a de escravo) se caracteriza como crime contra a organização do trabalho, de modo a atrair a competência da Justiça federal (art. 109, VI da Constituição) para processá-lo e julgá-lo. Recurso extraordinário conhecido e provido. ${ }^{46}$

Não obstante a decisão já proferida pelo STF, ainda há um recurso extraordinário (RE 459510) em tramitação interposto contra um acórdão da Terceira Turma do Tribunal Regional Federal da $1^{\circ}$ Região, que declarou competência da justiça estadual o julgamento do crime 149 do Código Penal ao analisar um caso de trabalho escravo no Mato Grosso. É a segunda vez que o STF deve decidir sobre o tema.

No dia $1^{\circ}$ de julho de 2014, o até então presidente do Supremo, ex-ministro Joaquim Barbosa, proferiu o voto-vista no julgamento, mantendo a competência da Justiça Federal. Sobre o tema, declarou:

Quaisquer condutas que possam ser tidas como violadoras não somente ao sistema de órgãos e instituições com atribuições para proteger os direitos e deveres dos trabalhadores, mas também do homem trabalhador, atingindoo nas esferas que the são mais caras em que a Constituição Federal confere proteção máxima, são sim enquadráveis na categoria dos crimes contra a organização do trabalho e praticados no contexto de relações do trabalho. ${ }^{47}$

Caso seja declarada a incompetência da Justiça Federal, todos os processos que estão em andamento devem ser remetidos à Justiça Estadual. O que ocasionaria a prescrição de inúmeras ações penais e a impunidade de muitos criminosos.

\footnotetext{
${ }^{46}$ Supremo Tribunal Federal. RE 398.041, rel. min. JOAQUIM BARBOSA, DJ 19.12.2008.

${ }^{47}$ Supremo Tribunal Federal. Ministro Joaquim Barbosa. Julgamento do RE 459510, em 01.07.2014.
} vol.08, n. 03, Rio de Janeiro, 2015.pp. 1334-1368 


\section{ATUAÇÃO CONTRA O TRABALHO ESCRAVO}

Por mais de três séculos a escravidão permaneceu no Brasil, iniciando-se com a escravidão indígena e permanecendo com a escravidão dos negros africanos. Porém, a abolição da escravatura não foi o seu término, apenas se iniciou um novo tipo de exploração do ser humano.

O trabalho escravo adquiriu novas formas. O pretexto para escravizar, atualmente, é a condição econômica da vítima, não mais sendo a raça o fator determinante. Além de ter se tornado uma prática ilegal, sendo considerada crime, passando a ser combatida mundialmente.

Apesar da ilegalidade, por muitas décadas a escravização foi "esquecida" pelo Governo brasileiro. Gradativamente, atores e grupos nacionais e internacionais conseguiram que o tema tivesse destaque nas questões sociais, fazendo com que na década de 1990 o Governo brasileiro reconhecesse a existência da escravidão no Brasil, tornando o assunto objeto de discussão e prevendo medidas para sua erradicação ${ }^{48}$.

É importante destacar as competências e ações dos principais órgãos governamentais no combate ao trabalho escravo. O Ministério do Trabalho e Emprego, por sua fiscalização através do Grupo Especial de Fiscalização Móvel, o Ministério Público do Trabalho, atuando através de seus Procuradores com interposição das medidas judiciais e extrajudiciais e o Ministério Público Federal e a Polícia Federal na questão criminal ${ }^{49}$.

Neste sentido, o Plano Nacional para erradicação do trabalho escravo é um programa governamental, elaborado pela Comissão Especial do Conselho de Defesa dos Direitos da Pessoa Humana (CDDPH), lançado em 10 de março de $2003^{50}$.

No programa constam diversas metas a serem cumpridas em curto, médio e longo prazo, que visam a melhoria na Estrutura Administrativa dos órgãos atuantes no combate ao trabalho escravo, promoções de ações de cidadania na conscientização e sensibilização da sociedade e o combate à impunidade.

Após avaliações na implantação do primeiro Plano, em 2008 foi lançado o "Segundo Plano Nacional para Erradicação do Trabalho Escravo", com modificações e melhorias, como por exemplo, um maior investimento na inserção do trabalhador resgatado no mercado de trabalho e o aumento de fiscalizações prévias, sem que se tenha que esperar denúncias. ${ }^{51}$

\footnotetext{
${ }^{48}$ Trabalho escravo contemporâneo: Um debate transdisciplinar / Ricardo Rezende Figueira, Adonia Antunes Prado, Horácio Antunes de Sant'Ana Júnior, organizadores. Rio de Janeiro: Mauad X, 2011.pp. 254-255.

${ }^{49}$ NEVES, Débora Maria Ribeiro. Trabalho escravo e aliciamento. São Paulo: LTR, 2012, pp. 85.

${ }^{50}$ Disponível em: http://portal.mte.gov.br/trab_escravo/plano-nacional-para-erradicacao-do-trabalho-escravo.htm. Acesso em 18 de outubro de 2014 .

${ }^{51}$ Trabalho escravo contemporâneo: Um debate transdisciplinar / Ricardo Rezende Figueira, Adonia Antunes Prado, Horácio Antunes de Sant'Ana Júnior, organizadores. Rio de Janeiro: Mauad X, 2011.pp. 254-255.
} vol.08, nº.03, Rio de Janeiro, 2015.pp. 1334-1368 1356 
A Comissão Nacional para a Erradicação do Trabalho Escravo (Conatrae) foi criada, em 2003, para monitorar e coordenar as metas previstas no programa, estando vinculada à Secretaria de Direitos Humanos da Presidência da República (SDH) e é composta por representantes governamentais e não-governamentais.

No "Segundo Plano Nacional para Erradicação do Trabalho Escravo" ${ }^{2}$ consta que "68,4\% das metas estipuladas pelo primeiro Plano Nacional foram atingidas, total ou parcialmente, segundo avaliação realizada pela Organização Internacional do Trabalho - OIT", significando grande avanço do país no combate à escravidão e na inserção dos resgatados na comunidade.

Instituído originalmente pelas Portarias n. ${ }^{\circ}$ 1.234/2003/MTE e 540/2004/MTE, o "Cadastro de Empregadores que Mantiveram Trabalhadores em Condições Análogas à de Escravos”, mais conhecido como "Lista Suja", contém o nome dos empregadores, físicos ou jurídicos, que foram flagrados na fiscalização.

Importante destacar que, conforme o artigo $2^{\circ}$ da Portaria Interministerial no $2 / 2011$, o nome do infrator só contará no cadastro após decisão administrativa final relativa ao auto de infração, sendo garantidos a ampla defesa e o contraditório. Segundo o art. $3^{\circ}$ da referida Portaria, a lista é atualizada semestralmente, sendo divulgada para diversas entidades governamentais e algumas entidades da sociedade civil. Quais sejam:

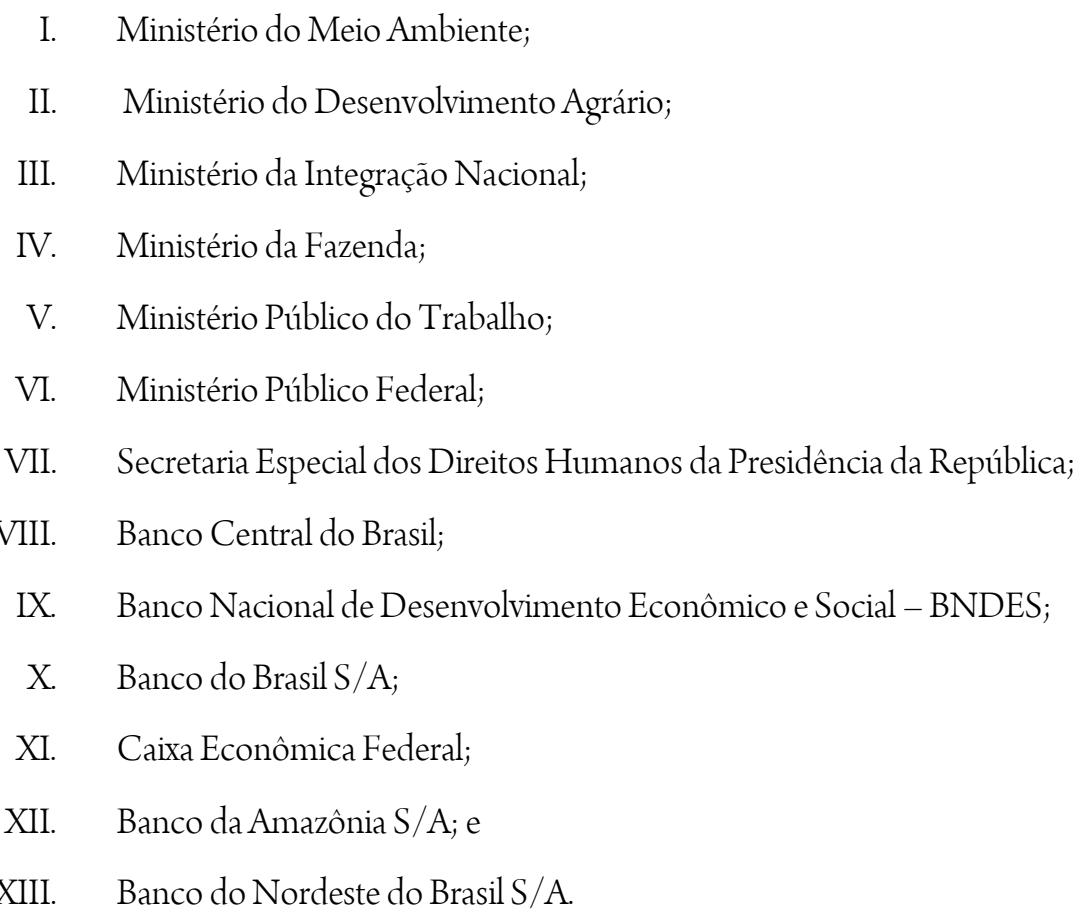

Após a inclusão, as empresas flagradas com o trabalho escravo são monitoradas por dois anos consecutivos. Durante o período, caso não haja reincidência, se as situações dos trabalhadores forem regularizadas com os débitos trabalhistas e previdenciários quitados e se todas multas da fiscalização forem pagas, o empregador

52 Disponível em: http://portal.mte.gov.br/data/files/8A7C816A39E4F614013AD5A314335F16/novoplano-nacional.pdf. Acessado em 18 de outubro de 2014. 
tem retirado seu nome do Cadastro de Empregadores que Mantiveram Trabalhadores em Condições Análogas à de Escravos.

Caso os requisitos não sejam cumpridos, o nome da pessoa, física ou jurídica, permanece, impedindo a concessão de crédito rural e benefícios fiscais em seu favor, de acordo com o previsto pela Resolução n ${ }^{\circ}$ $3876 / 2010$, em seu artigo $1^{\circ}$ :

Fica vedada às instituições financeiras integrantes do Sistema Nacional de Crédito Rural (SNCR) a contratação ou renovação, ao amparo de recursos de qualquer fonte, de operação de crédito rural, inclusive a prestação de garantias, bem como a operação de arrendamento mercantil no segmento rural, a pessoas físicas e jurídicas inscritas no Cadastro de Empregadores que mantiveram trabalhadores em condições análogas à de escravo instituído pelo Ministério do Trabalho e Emprego, em razão de decisão administrativa final relativa ao auto de infração.

O objetivo da Lista Suja é garantir a integralização dos diversos entes governamentais e a garantia de diversos princípios fundamentais, como o da dignidade da pessoa humana (artigo 1º, III da CRFB/88), e o bem estar dos trabalhadores.

Segundo entendimento do Superior Tribunal de Justiça, o Cadastro de Empregadores é um meio legítimo no combate ao trabalho escravo, estando de acordo com a Constituição Federal, legislação infraconstitucional e com os tratados e convenções internacionais em que o Brasil ratificou ${ }^{53}$. Neste sentido, temse:

Administrativo. Mandado de segurança. Portaria mte 540/2004. Inclusão do nome da impetrante no cadastro de empregadores que tenham mantido trabalhadores em condição análoga à de escravo. Ato determinado pelo ministro de estado do trabalho e emprego em avocatória ministerial. Legitimidade passiva. Ausência de violação dos princípios da legalidade e da presunção de inocência. Legitimidade da atuação dos auditores- fiscais do trabalho. Inadequação do mandado de segurança para verificar se a empresa pratica trabalho escravo.

1. Hipótese em que o Mandado de Segurança foi impetrado contra ato imputado ao Ministro de Estado do Trabalho e Emprego, referente à determinação de inclusão do nome da impetrante no cadastro de empregadores que tenham mantido trabalhadores em condição análoga à de escravo, instituído pela Portaria 540/2004 do Ministério do Trabalho e Emprego.

2. Os fatos descritos nos Autos de Infração lavrados contra a impetrante são extremamente graves: condições degradantes de trabalho; alojamentos superlotados (onde os empregados dormiam em redes); retenção intencional de salários; jornada excessiva, com início às 4h30; não-fornecimento de água potável; intervalos menores que uma hora para repouso e alimentação dos trabalhadores; proibição expressa de que os obreiros pudessem parar para comer o lanche que eles mesmos levavam para as

${ }^{53}$ NEVES, Débora Maria Ribeiro. Trabalho escravo e aliciamento. São Paulo: LTR, 2012, pp. 116 vol.08, nº. 03, Rio de Janeiro, 2015.pp. 1334-1368 
frentes de trabalho; recibos de pagamentos com valores zerados ou irrisórios; inexistência de instalações fixas ou móveis de vasos sanitários e lavatórios [...]

4. Em síntese, a impetrante alega que: a) a Portaria 540/2004 é inconstitucional, pois fere o Princípio da Legalidade e o da Presunção de Inocência; b) os auditores fiscais do trabalho carecem de atribuição legal para fiscalizar a empresa; c) não há trabalho escravo em suas dependências.

5. No Direito Constitucional contemporâneo, inexiste espaço para a tese de que determinado ato administrativo normativo fere o Princípio da Legalidade, tão-só porque encontra fundamento direto na Constituição Federal. [...]

8. A Portaria MTE 540/2004 concretiza os princípios constitucionais da Dignidade da Pessoa Humana (art. 1o, III, da CF), da Valorização do Trabalho (art. 1º, IV, da CF), bem como prestigia os objetivos de construir uma sociedade livre, justa e solidária, de erradicar a pobreza, de reduzir as desigualdades sociais e regionais e de promover o bem de todos (art. $3^{\circ}$, I, III e IV, da CF). Em acréscimo, foi editada em conformidade com a regra do art. 21, XXIV, da CF, que prescreve ser da competência da União "organizar, manter e executar a inspeção do trabalho." Por fim, não se pode olvidar que materializa o comando do art. 186, III e IV, da CF, segundo o qual a função social da propriedade rural é cumprida quando, além de outros requisitos, observa as disposições que regulam as relações de trabalho e promove o bem-estar dos trabalhadores.

9. Some-se a essas normas o disposto no art. 87, parágrafo único, I e II, da Constituição de 1988, pelo qual compete ao Ministro de Estado, entre outras atribuições estabelecidas na Constituição e na lei, exercer a orientação, coordenação e supervisão dos órgãos e entidades da administração federal na área de sua competência e "expedir instruções para a execução das leis, decretos e regulamentos".

10. Além de ter fundamento na Constituição, a Portaria 540/2004 encontra amparo na legislação infraconstitucional. O art. $913 \mathrm{da}$ Consolidação das Leis do Trabalho é claro ao estabelecer que "o Ministro do Trabalho, Indústria e Comércio expedirá instruções, quadros, tabelas e modelos que se tornarem necessários à execução desta Consolidação." [...]

13. No mais, a impetrante alega que a redução do trabalhador à condição análoga à de escravo é crime (art. 149 do Código Penal) e, como tal, a constatação administrativa de sua prática só pode produzir efeitos após o trânsito em julgado de sentença condenatória, sob pena de violação do Princípio da Presunção de Inocência.

14. Como se sabe, no Direito brasileiro, as instâncias penal, civil e administrativa não se confundem. Vale dizer: se o processo administrativo observou os trâmites legais, e nele foi produzida prova suficiente para bem caracterizar a conduta reprovável, a sanção (ou, no caso dos autos, medida administrativa) pode ser aplicada independentemente de prévia condenação criminal.

15. No caso dos autos, conforme regra inscrita no art. $2^{\circ}$ da Portaria 540/2004, a determinação para inclusão do nome da empresa no 
Cadastro foi tomada após decisão final em processo administrativo que observou os Princípios da Ampla Defesa e do Contraditório. [...]

20. O trabalho escravo - e tudo o que a ele se assemelhe - configura gritante aberração e odioso desvirtuamento do Estado de Direito, sobretudo em era de valorização da dignidade da pessoa, dos direitos humanos e da função social da propriedade.

21. O Poder Público acha-se obrigado, pela Constituição e pelas leis, não só a punir com rigor o trabalho escravo e práticas congêneres, como a informar à sociedade sobre a sua ocorrência, por meio de mecanismos como o cadastro de empregadores: em síntese, um modelo oposto ao silêncio- conivência da Administração, que até recentemente era a tônica da posição do Estado em temas de alta conflituosidade. [... ${ }^{54}$

Conforme a atualização semestral da data de 01 de julho de 2014, no Cadastro consta, atualmente, 609 (seiscentos e nove) empregadores flagrados mantendo trabalhadores submetidos à condição análoga à de escravo. Desde a última atualização semestral, foram incluídos 91 (noventa e um) empregadores e excluídos 48 (quarenta e oito) empregadores, por cumprirem os requisitos administrativos exigidos.

De acordo com o MTE, o estado do Pará apresenta o maior número de empregadores inscritos na lista, totalizando cerca de 27\%, sendo seguido por Minas Gerais com 11\%, Mato Grosso com 9\% e Goiás com 8\%. A pecuária constitui a atividade econômica desenvolvida pela maioria dos empregadores (40\%), seguida da produção florestal (25\%), agricultura (16\%) e indústria da construção $(7 \%)^{55}$.

É também digno de nota que a Constituição Federal, em seu artigo 21, XXIV, confere à União o dever de organizar, manter e executar a inspeção do trabalho. Por meio do Ministério do Trabalho e Emprego, o Estado atua na sociedade para conferir aos cidadãos o gozo dos direitos constitucionais em relação aos trabalhadores, garantindo sua eficácia.

O MTE possui competência para fiscalizar o cumprimento das normas trabalhistas, podendo firmar termos de compromissos, aplicar multas, lavrar autos de infração e expedir Normas Regulamentadoras, descrevendo os requisitos de segurança, saúde e higiene dos trabalhadores ${ }^{56}$.

A principal ação do até então Presidente da República Fernando Henrique Cardoso sobre a questão do combate ao trabalho escravo foi, em seu primeiro mandato, a criação do "Grupo Executivo de Repressão ao Trabalho Forçado" (GERTRAF), ligado ao Ministério do Trabalho e Emprego, que, por sua política antiescravista, estabeleceu o "Grupo Especial de Fiscalização Móvel" (GEFM), formado por auditores-fiscais do

\footnotetext{
${ }^{54}$ Superior Tribunal de Justiça. Primeira Seção. Relator: Herman Benjamin. Mandado de Segurança no 14017 - DF, processo n²008/0271496-6. Julgado em 27 de maio de 2009.

55 Disponível em: http://portal.mte.gov.br/trab_escravo/portaria-do-mte-cria-cadastro-de-empresas-e-pessoas-autuadas-porexploracao-do-trabalho-escravo.htm. Acesso em 12 de outubro de 2014.

${ }^{56}$ NEVES, Débora Maria Ribeiro. Trabalho escravo e aliciamento. São Paulo: LTR, 2012, pp. 88. 
trabalho, Policiais Federais e Procuradores do Trabalho e coordenado pela Secretaria de Inspeção do Trabalho do Ministério do Trabalho e Emprego.

O GEFM foi criado com o objetivo de unificar a forma de combate a escravidão. Um comando central é capaz de padronizar os procedimentos e garantir sigilo às denúncias sobre possíveis locais de exploração. Dessa forma, os fiscais possuem maior proteção contra as ameaças dos grandes fazendeiros, fazendo cumprir os direitos trabalhistas, resgatando as vítimas do crime ${ }^{57}$.

O Grupo Especial é coordenado pela Secretaria de Inspeção do Trabalho e possui atuação em todo o território nacional, agindo em conjunto com demais órgãos, como a Polícia Federal e o Ministério Público Federal.

Além do combate à escravidão, o Ministério do Trabalho e Emprego possui ações de assistência e inclusão dos trabalhadores resgatados. O órgão providencia hospedagem e alimentação aos escravizados enquanto ocorre a ação fiscal.

A Lei n. 10.608/2002 concedeu ao trabalhador resgatado em condição análoga à de escravo o direito de receber, no valor de um salário mínimo, três parcelas do seguro-desemprego. Sendo competência dos auditores fiscais, no momento do resgate, fazer o requerimento para a concessão do benefício, que é sacado diretamente pelo trabalhador em agência bancária.

O MTE também é responsável pelo encaminhamento do trabalhador, através do Sistema Nacional de Emprego - SINE, para qualificação profissional. O programa objetiva reintroduzir o trabalhador no mercado de trabalho, o encaminhando à intermediação de mão de obra, tornando desnecessária a figura do "gato" e prevenindo o aliciamento.

O MTE ainda possui parceria com o Ministério do Desenvolvimento Social e Combate à Fome (MDS) que concede prioridade aos trabalhadores resgatados ao programa Bolsa Família e com o Ministério da Educação (MEC) que inclui os escravizados no programa Brasil Alfabetizado.

Já o Ministério Público do Trabalho (MPT) integra o Ministério Público da União (MPU) e está previsto no artigo 127 e seguintes da Constituição Federal. Sua função, dentre outras, é a defesa dos interesses sociais e individuais indisponíveis com competência da Justiça do Trabalho, atuando especialmente nos temas de trabalho infantil, trabalho escravo e discriminações no mercado de trabalho.

O MPT atua por meio de seus Procuradores do Trabalho, que participam diretamente nas ações de fiscalização realizadas pelo Grupo Especial de Fiscalização Móvel e conta com quatro principais instrumentos

\footnotetext{
${ }^{57}$ Trabalho escravo contemporâneo: Um debate transdisciplinar / Ricardo Rezende Figueira, Adonia Antunes Prado, Horácio Antunes de Sant'Ana Júnior, organizadores. Rio de Janeiro: Mauad X, 2011.pp. 254-255. 
para proteção dos direitos constitucionais e trabalhistas: Inquérito Civil, Ação Civil Pública, Ação Civil coletiva e Termo de Ajustamento de Conduta ${ }^{58}$.

O Inquérito Civil pode ser definido da seguinte maneira:

O inquérito civil constitui-se numa investigação administrativa realizada previamente pelo Ministério Público, objetivando colher elementos e provas que determinem o manejo, ou não, da respectiva ação civil pública ou de outra medida judicial cabível. Logo, o inquérito civil, de competência exclusiva do Ministério Público, é o principal instrumento, de natureza investigatória, concernente à atuação extrajudicial do Ministério Público do Trabalho ${ }^{59}$.

Sobre o combate ao trabalho escravo, a investigação de possíveis irregularidades das normas trabalhistas é realizada durante a própria fiscalização do GEFM, se tornando um instrumento necessário apenas quando o MPT não está presente nas devidas fiscalizações ou quando deverá ser apurada alguma denúncia.

O Procurador do Trabalho, presente na fiscalização ou que estiver responsável pelo Inquérito Civil, pode propor o ajuizamento da Ação Civil Pública, por via judicial, ou realizar um Termo de Ajuste de Conduta (TAC), onde a situação é solucionada por via administrativa ${ }^{60}$.

A Ação Civil Pública é regulada pela Lei n. 7347/1985 e estabelecida no âmbito trabalhista por meio da Lei Complementar n. 75/93. Consta ainda na Constituição Federal em seu artigo 83:

Art.83. Compete ao Ministério Público do Trabalho o exercício das seguintes atribuições junto aos órgãos da Justiça do Trabalho: III- promover a ação civil pública no âmbito da Justiça do Trabalho, para defesa de interesses coletivos, quando desrespeitados os direitos sociais constitucionalmente garantidos

A ACP é utilizada como meio de justiça social. Sua finalidade é defender os direitos e interesses metaindividuais constitucionais garantidos aos trabalhadores, que por sua hipossuficiência não tem acesso à via judicial, sendo competente a Justiça do Trabalho para solucionar a lide, com base nos artigos 127 a 129 da Constituição Federal.

A defesa desses direitos pode se dar na prevenção ou reparação dos danos, materiais e imateriais, causados aos trabalhadores. A ACP objetiva punir os responsáveis pela escravização, ressarcindo as vítimas e impedindo a reincidência do crime. A indenização por dano moral coletivo é revertida para o Fundo de Amparo ao Trabalhador (FAT).

Além da ACP, o MPT é legitimado para firmar o Termo de Ajuste de Conduta, resolvendo o litígio por via administrativa. Sobre a questão, o Procurador do Trabalho, Cícero Rufino Pereira, preceitua:

Muitas vezes, até para o Procurador do Trabalho oficiante no ICP instaurado para combater as formas modernas de escravidão é mais

\footnotetext{
${ }^{58}$ NEVES, Débora Maria Ribeiro. Trabalho escravo e aliciamento. São Paulo: LTR, 2012, pp. 101.

${ }^{59}$ SARAIVA, Renato. Curso de Direito Processual do Trabalho. São Paulo: Método, 2007.p. 722.

${ }^{60}$ LOTTO, Luciana Aparecida. Ação Civil Pública Trabalhista Contra o Trabalho Escravo no Brasil. São Paulo: LTr,2008. p.82. vol.08, nº. 03, Rio de Janeiro, 2015.pp. 1334-1368 1362
} 
interessante e produtivo firmar o TAC, a ter que ajuizar a ACP, com todas as delongas e dificuldades de produção de prova que esse tipo de remédio jurídico impõe. Sem falar da necessidade premente de convencer a 'empresa' inquirida de pagar os direitos trabalhistas dos empregados espoliados, bem como devolvê-los a seu local de origem.

Daí, muitas vezes, o caminho mais pragmático a se seguir é o de se firmar o Termo de Ajuste de Conduta, em detrimento da Ação Civil Pública. Até porque o Termo de Ajuste de Conduta tem força cogente de Título Executivo Extrajudicial, que já era admitido pela doutrina e jurisprudência e encontrou legitimação na Lei n. 9.948/2000, a qual deu nova redação ao artigo 876, da CLT. ${ }^{61}$

O Poder Judiciário Trabalhista é considerado demorado e caro, estando as vítimas mais expostas a sofrerem acidentes e danos irreparáveis ao passar do tempo. Em contrapartida, o TAC é uma solução rápida e não onerosa, devendo constar a obrigação líquida e certa, multa, se devida e ainda possui força de título executivo extrajudicial, ou seja, se não cumprido, há a possibilidade de execução judicial. ${ }^{62}$

Por fim, a ação Civil Coletiva é um instrumento com o objetivo de defender os direitos individuais homogêneos, ou seja, direitos limitados a um grupo de trabalhadores específicos. Como exemplo, os trabalhadores em situação análoga à de escravo, sendo a indenização revertida aos próprios trabalhadores.

Diante do exposto, verifica-se que o MPT possui diversos instrumentos para o combate à escravidão. Em 2001, foi criada a Coordenação Nacional de Erradicação do Trabalho Escravo (CONAETE), formada por procuradores do trabalho e que se destina a acompanhar as fiscalizações realizadas pelo GEFM, pelo MTE, tornando-se indispensável na repressão às práticas anti-trabalhistas.

Após o posicionamento do STF, em que considerou reduzir alguém à condição análoga à de escravo um crime contra a coletividade dos trabalhadores, determinando a Justiça Federal como competente para julgar o crime do artigo 149 do Código Penal, o Ministério Público Federal teve maior atuação na questão.

No âmbito Criminal, a Polícia Federal possui maior atuação na fiscalização, estando presente diretamente nas operações, tornando possível a apreensão de armas e prisões em flagrantes. O MPF atua a partir do recebimento dos relatórios do GEFM, sendo fundamental no recebimento de denúncias e na condenação de empregadores $^{63}$.

Existem ainda diversas entidades não governamentais no combate à valorização do capital em detrimento do trabalho. Entretanto, duas entidades se tornaram fundamentais no combate ao trabalho escravo com prestações de serviços de informação e fiscalização, quais sejam: a Comissão da Pastoral da Terra e a ONG Repórter Brasil.

\footnotetext{
${ }^{61}$ O Termo de Ajuste de Conduta firmado pelo MP no Combate ao Trabalho Escravo e a Defesa da Exceção de PréExecutividade, Revista do Ministério Público do Trabalho, Edição Especial. Trabalho Escravo, p. 114.

${ }^{62}$ LOTTO, Luciana Aparecida. Ação Civil Pública Trabalhista Contra o Trabalho Escravo no Brasil. São Paulo: LTr,2008. p.8388.

${ }^{63}$ LOTTO, Luciana Aparecida. Ação Civil Pública Trabalhista Contra o Trabalho Escravo no Brasil. São Paulo: LTr,2008. p.109. vol.08, no. 03, Rio de Janeiro, 2015. pp. 1334-1368 1363
} 
A Comissão Pastoral da Terra foi fundada em 1975, em um Encontro da Pastoral da Amazônia, realizado na Cidade de Goiânia, convocado pela Conferência Nacional dos Bispos do Brasil (CNBB).

É uma entidade não governamental que luta pelo trabalhador rural e possui como precursor os direitos humanos. Dessa forma, em cada estado, a CPT pode modificar o motivo e a sua forma de atuação.

Sobre o trabalho escravo a sua principal área de atuação está nos estados do Pará, Maranhão, Mato Grosso e Tocantins, com a campanha preventiva: "De olho aberto para não virar escravo!".

A campanha tem como principal forma de prevenção a informação. São distribuídos materiais didáticos aos trabalhadores constando alguns direitos trabalhistas, telefones para denúncia e as características de um aliciamento.

A CPT possui parcerias com o Ministério Público do Trabalho em que anualmente analisa numericamente a situação do Brasil em relação ao tema, divulgando os resultados para a sociedade. Conforme a organização, no ano de 2013, foram resgatadas 2.254 pessoas trabalhando em regime análogo à escravidão ${ }^{64}$.

A Repórter Brasil foi fundada em 2001, por cientistas, jornalistas e educadores com o objetivo de refletir e discutir sobre a situação dos trabalhadores do Brasil e a violação aos seus direitos fundamentais. Dessa forma, se tornou grande incentivadora no combate ao trabalho escravo. Suas pesquisas e investigações são usadas pelo poder público como instrumento para o combate à exploração do trabalho no país.

A entidade por ser independente, possui liberdade para produzir suas investigações e construir parcerias com diversas organizações públicas e privadas. Além de que a Repórter Brasil une a luta contra a violação da dignidade humana com a técnica e rigor profissional, produzindo um conhecimento de referência ${ }^{65}$. A sua atuação não se limita a elaborar artigos científicos e pesquisas sobre o tema. A organização propõe formar lideranças populares na causa, participa na distribuição de materiais didáticos sobre o tema e possui um programa de prevenção ao aliciamento conhecido como: "Escravo, nem pensar!” (ENP).

O ENP é o primeiro programa de educação e conscientização da população contra o aliciamento para o trabalho escravo em âmbito nacional. Atua em áreas de grande vulnerabilidade social e baixo índice de educação. A organização acredita que além da fiscalização e punição dos empregadores, o combate ao trabalho escravo deve atuar na prevenção essa prática. O programa foi incluído no Plano Nacional de Erradicação ao Trabalho Escravo $^{66}$.

Por fim, cumpre destacar a Organização Internacional do Trabalho, fundada como parte no Pacto de Versalhes, em 1919, que encerrou a primeira Guerra Mundial. Sua composição é tripartite, com representante do governo, empregadores e empregados.

\footnotetext{
${ }^{64}$ Disponível em: http://www.cptnacional.org.br/attachments/article/2258/S\%C3\%ADntese\%20estat\%C3\%ADstica\%20do\%20TE\%202013\%20-\%20ATUALIZADA\%20em\%2023.06.2014.pdf. Acesso em 16 de out. de 2014.

${ }^{65}$ Disponível em http://reporterbrasil.org.br/quem-somos/. Acesso em 16 de out. de 2014.

${ }^{66}$ Disponível em http://reporterbrasil.org.br/quem-somos/. Acessado em 16 de out. de 2014. vol.08, nº. 03, Rio de Janeiro, 2015.pp. 1334-1368 
A criação da organização advém da ideia de que a justiça social é quem garante a paz mundial. Dessa forma, promove normas e ações para que todos os homens e mulheres possam ter direito a trabalho digno e decente ${ }^{67}$.

A OIT é a organização responsável por editar tratados e convenções internacionais do trabalho que, se ratificados por determinado país, passam a compor o seu ordenamento jurídico. O Brasil ratificou importantes Convenções da OIT sobre o combate à escravidão, se comprometendo a erradicar a exploração do trabalho sob qualquer forma.

A Organização internacional e o governo brasileiro, em 2002, deram início ao projeto "Combate ao Trabalho Escravo no Brasil", para ajudar o país a cumprir as convenções no 29 e no 105 da OIT e fortalecer os órgãos que atuam na supressão do trabalho escravo. O projeto apoia iniciativas do Governo Federal e integra todas as entidades nacionais, governamentais e não governamentais, na defesa da dignidade humana. Significativos avanços já foram conquistados, como o aumento da punição aos empregadores e o envolvimento de empresas privadas, que já se comprometem a não mais comprar produtos de empresas que utilizam a mão de obra escrava.

A erradicação da escravidão ainda é uma missão a longo prazo, porém o Brasil já possui reconhecimento e ajuda internacional na luta dos Direitos Humanos, sendo uma importante ferramenta para pôr fim à exploração ilegal e degradante no país.

\section{CONCLUSÃO}

Após a comparação entre a escravidão colonial e contemporânea, percebe-se que o Brasil sempre teve uma cultura escravocrata. E é inegável que submeter alguém à condição análoga à de escravo ainda é uma prática existente no país.

A escravidão fere o princípio constitucional da dignidade da pessoa humana, que garante direitos mínimos ao cidadão. A Constituição Federal de 1988 contém dispositivos que regem a relação dos humanos em sociedade, inclusive no âmbito laboral e assegura a justiça social. Ao ser violada, a pessoa humana se torna vulnerável e desprotegida.

O trabalho é o maior bem do ser humano, pois dele depende sua sobrevivência. $\mathrm{O}$ ato de escravizar é retirar do trabalhador os seus direitos como pessoa, é ignorar a função social do labor e desrespeitar todas as normas brasileiras.

Daí decorre a importância da questão: a atuação contra o trabalho escravo é dificultada devido a grandes burocracias, a lentidão da justiça, a extensão territorial e a desigualdade socioeconômica.

\footnotetext{
${ }^{67}$ Disponível em: http://www.oitbrasil.org.br/content/apresenta\%C3\%A7\%C3\%A3o. Acesso em 18 de out. de 2014. vol.08, nº. 03, Rio de Janeiro, 2015.pp. 1334-1368
} 
As vítimas são em sua maioria de origem pobre, analfabetos e excluídos socialmente e por isso não possuem oportunidades de trabalho, sendo a proposta dos aliciadores seu único modo de sobrevivência. Daí a emergência de um Poder Judiciário eficiente. O Estado deve ser capaz de punir severamente àquele que ignora suas normas e desrespeita a vida e dignidade de uma pessoa.

Porém, a impunidade para quem comete esse tipo de crime é algo sabido. Quando condenados, as penas ainda podem ser revestidas em doações de cestas básicas. Diante disso, os empregadores não se sentem intimidados a não mais praticá-los, sendo mais vantajoso economizar nos direitos trabalhistas e voltar a praticar o crime.

Apesar dos tratados internacionais ratificados pelo Brasil e o compromisso de realizar políticas públicas eficientes, a erradicação do trabalho escravo ainda é uma meta a longo prazo a ser cumprida pelo Estado.

Com a atuação tardia, o combate preventivo é quase inexistente e a impunidade se faz presente, fazendo com que as provas da ilegalidade sejam camufladas, voltando a se repetir.

O Estado deve investir na forma de atuação preventiva no combate ao crime. Estimular políticas de educação e investir na formação política, econômica e social do cidadão. Oferecer oportunidades de aperfeiçoamento de profissões e garantir um ensino de qualidade é um método eficiente para evitar o aliciamento e impedir que o trabalhador se submeta a condições sub humanas para sobreviver. Além disso, após o resgate, é imprescindível que o Estado tenha condições de amparar o trabalhador, evitando assim, a reincidência dos empregadores.

É importante destacar a necessidade de uma ação conjunta de todos os institutos na erradicação do trabalho escravo. Dentre eles, obtêm destaque o Ministério Público, a Polícia Federal, o Ministério do Trabalho e Emprego e as instituições não governamentais.

A lista suja do MTE, as fiscalizações dos procuradores, as apreensões da Policia Federal e as campanhas informativas e formadoras de opinião das ONG's, de forma isolada, não combatem a prática ilegal, devendo ser realizadas concomitantemente.

A promulgação da Emenda Constitucional n. 81, em 27/05/2014, conhecida como a "PEC do Trabalho Escravo" de n. 438/2001, que permite que as propriedades rurais e urbanas, onde for localizada a prática do trabalho escravo, sejam expropriadas e destinadas a reforma agrária e a programas de habitação popular, sem direito a indenização ao proprietário, foi uma importante medida do governo no combate ao trabalho escravo.

Com uma política de conscientização dos trabalhadores acerca de seus direitos, uma eficaz reinserção dos escravizados à sociedade e uma maior rigidez na aplicação de penalidades aos empregadores, o Brasil poderá oferecer não apenas a liberdade física, mas sim a liberdade de escolha por trabalhos decentes e dignos aos trabalhadores do país, acabando de vez com uma prática que já teve seu fim decretado há séculos. 


\title{
SLAVE LABOR IN CONTEMPORARY BRAZIL
}

\begin{abstract}
The scope of this article is to evaluate existing forms of contemporary slavery in Brazil, its current concept, its possible causes and the characters involved. Will be exposed to a brief history of labor law and slavery, then, will be evaluated which are the main rights violated with their practice and the main factors for its persistence. Contains the description of governmental and non-governmental measures to eradicate the crime of exposing someone to a condition analogous to slavery, as the existing laws, social programs and international treaties ratified by Brazil. The aim is to present a common practice in the country, which is held covertly, almost imperceptible, in order to educate society about the problem, about the importance of assistance to workers rescued and analyze what can be done to combat submission of a citizen to the sub human conditions.
\end{abstract}

Keywords: Slavery; National Plan to Eradicate Slavery Work; International conventions and treaties.

\section{REFERENCIAS}

BARROSO, Luís Roberto. Curso de Direito Constitucional Contemporâneo: Os conceitos fundamentais e a construção do novo modelo. $2^{\circ}$ Ed. São Paulo; Saraiva, 2010.

BERNARDES, Hugo Gueiros. Direito do Trabalho. São Paulo: LTr. V. 1, 1989.

BRITO FILHO, José Claudio Monteiro de. Trabalho Decente: Análise jurídica da exploração do trabalho: trabalho escravo e outras formas de trabalho indigno. 3 ed. São Paulo: LTR, 2013.

CARVALHO, Augusto Cesar Leite de. Direito do Trabalho: Curso e Discurso. [Recurso eletrônico]. Aracaju: Evocati, 2011.

DELGADO, Godinho Mauricio. Curso de Direito do Trabalho. Edição 9. São Paulo: LTr, 2010.

FIGUEIRA, Ricardo Rezende; PRADO, Adonia Antunes; SANT'ANA JÚNIOR, Horácio Antunes de, (organizadores). Trabalho escravo contemporâneo: Um debate transdisciplinar. Rio de Janeiro: Mauad X, 2011.

GOMES, Orlando; GOTTSCHALK, Elson. Curso de Direito do Trabalho. Rio de janeiro: Forense, 1995.

LOTTO, Luciana Aparecida. Ação Civil Pública Trabalhista contra o Trabalho Escravo no Brasil. São Paulo: Revista dos Tribunais. 2008.

MAGANO, Octavio Bueno. Manual de Direito do Trabalho Parte Geral. São Paulo: LTr, V. 1, 1991.

MORAES FILHO, Evaristo de; MORAES, Antonio Carlos Flores de. Introdução ao Direito do Trabalho. São Paulo: Revista dos Tribunais, 1995.

MARTINS, Sergio Pinto. Direito do Trabalho. Edição 20. São Paulo: ATLAS S.A, 2004.

MELLO, Celso Antônio Bandeira de. Curso de Direito Administrativo. Edição 8. São Paulo: Malheiros, 1997. 
MORAES, Alexandre de. Direito Constitucional. Edição 26. São Paulo: Atlas S.A., 2010.

NEVES, Débora Maria Ribeiro. Trabalho Escravo e Aliciamento. São Paulo: Revista dos Tribunais, 2012.

NETO, Vito Palo. Conceito jurídico e combate ao trabalho escravo contemporâneo. São Paulo: Revista dos Tribunais, 2008.

NOCCHI, Andrea Saint Pastous; VELLOSO, Gabriel Napoleão; FAVA, Marcos Neves; (coordenadores). Trabalho Escravo Contemporâneo: $O$ desafio de superar a negação. $2^{\circ}$ edição. São Paulo: Revista dos Tribunais, 2011.

NUCCI, Guilherme de Souza. Código Penal Comentado. 10 ed. Versão Atualizada e Ampliada. São Paulo: Revista dos Tribunais, 2010.

ORGANIZAÇÃO DAS NAÇÕES UNIDAS. Report of the special rapporteur on contemporary forms of slavery, including its causes and consequences, Gulnara Shahinian: Mission to Brazil. Disponível em: www2.ohchr.org/English/bodies/hrcouncil/docs/15session/A.HRC.15.20..Add.4_en.pdf. Acesso em: 10 de outubro de 2014.

Portaria do MTE Cria Cadastro de Empresas e Pessoas Autuadas Por Exploração do Trabalho Escravo. Disponível em: http://portal.mte.gov.br/trab_escravo/portaria-do-mte-cria-cadastro-de-empresas-e-pessoasautuadas-por-exploracao-do-trabalho-escravo.htm. Acesso em: 12 de outubro de 2014.

REALE, Miguel. Lições Preliminares de Direito. 27a ed. São Paulo: Saraiva, 2003.

Revista Magister de Direito Trabalhista e Previdenciário, nº 38 - Setembro/Outubro 2010.

Revista do Ministério Público do Trabalho. Volume 26.

Revista TST, Brasília, vol. 69, n² 2, julho/dezembro 2003. Brasília, vol. 75, no 3, julho/setembro 2009.

ROLIM, Luis Antônio. Instituições de Direito Romano. São Paulo: Revista dos Tribunais, 2000.

SARAIVA, Renato. Curso de Direito Processual do Trabalho. São Paulo: Método, 2007.

SCHWARZ, Rodrigo Garcia. Direito do Trabalho. Rio de Janeiro, Ed. Elsevier, 2007

SÜSSEKIND, Arnaldo e outros. Instituições de Direito do Trabalho. V1. Edição 18, São Paulo: Revista dos Tribunais, 1999.

Trabalho enviado em 08 de fevereiro de 2015.

Aceito em 25 de abril de 2015. 